\title{
Memleketini Anlatan Seyyahlar: Trabzonlu Seyyahların Metinlerinde Trabzon
}

\author{
Dr. Öğr. Üyesi Fulya Üstün Demirkaya \\ Karadeniz Teknik Üniversitesi, Mimarlık Fakültesi \\ Mimarlık Bölümü \\ fulyastn@ktu.edu.tr
}

\author{
$\mathrm{Og} u z \mathrm{~K} \iota r \mathrm{cl}$ \\ Karadeniz Teknik Üniversitesi, Fen Bilimleri Enstitüsü \\ Doktora Öğrencisi \\ oguzkirci@gmail.com
}

Öz

Coğrafik ve stratejik konumunun sağladığı, doğu ve batı arasında ticari ve askeri, kara ve deniz bağlantısının merkezi olma rolü ile Trabzon, merak duygusuyla hareket eden birçok seyyahın gezi güzergâhında yerini almıştır. Bu metin, Trabzon kentini, yabancı bir ziyaretçinin gözlemlerinden daha fazlasını içeren, kendileri de Trabzonlu olmaları nedeniyle aynı zamanda deneyimleyen seyyahların gözünden anlamayı hedeflemektedir. Trabzon doğumlu olan Aşık Mehmed (16.yy), Minas Bijıskyan (19.yy) ve Şakir Şevket (19.yy) ile babası Trabzonlu olan İsmail Safa'nın (19.yy), kentin tarihi, yapıları, kitabeleri, sokakları, pazar ve mahalleleri, demografik yapısı ve halkın gündelik yaşamına ilişkin aktardıkları, zaman zaman birbiri ile çelişip zaman zaman örtüşen ve/veya birbirini tamamlayan bilgiler karşılaştııılarak değerlendirilmiştir. İsmail Safa'nın manzum eseri kentin fiziksel dokusu konusunda net bilgiler vermediği için çalışma kapsamında kullanılamamıştır. Seyahatnamelerde yer alan bilgilerin değerlendirilmesi temelde kentin fiziki dokusunu anlamaya yöneliktir. Bu nedenle seyyahların metinleri, kentin tarihsel olarak bulunduğu yer-topografyası ile fiziki dokusunun parçası olan liman, dini-askeri-ticari-sivil yapılar ve bu dokunun tamamlayıcısı mahalleler üzerine odaklanarak ele alınmıştır. Üç seyyahın verdiği bilgiler toplu olarak değerlendirildiğinde; Aşık Mehmed ve Şakir Şevket, ağırlıklı olarak kentin Osmanlı Dönemi dokusuna dikkat çekerken, Şakir Şevket ile aynı dönemi anlatmasına karşın Bıjışkyan ağırlıklı olarak Osmanlı öncesi veya Osmanlı dönemi gayrimüslim yapılarına vurgu yapar. Seyyahların yaşadıkları dönem ve sahip oldukları kimliklerinin (dini, siyasi, mesleki vb.) izleri metinlerde takip edilebilmektedir. Bu bağlamda seyyahlar memleketlerini kendi yaşam perspektifinden anlatırken, farklı hikâyelere ulaşmamıza, doğru bilinenlerin sorgulanmasına olanak tanımış, pek çok kaynakta bahsedilmeyen, varlığını bildiğimiz ancak takibini yapamadığımız, fiziki tanımlamanın mümkün olmadığı pek çok yapı/yere ilişkin betimlemeler ile önemli bilgi eksikliğinin tamamlanmasını sağlanmıştır.

Anahtar Kelimeler: Seyahatname, Trabzon, Aşık Mehmed, Minas Bıjışkyan, Şakir Şevket. 


\title{
Travellers who Tell about Their Hometown: Trabzon in the Texts of Travellers from Trabzon
}

\begin{abstract}
Trabzon attracts numerous travellers as it is the center of commercial and military as well as land and sea connection between the east and west. It has become a notable location on the travel route of many curious travellers given its geographical and strategic location. This study is aimed that Trabzon be viewed from the perspective of the travellers who studied the place in greater depth and experienced Trabzon as locals compared to the observations of foreign visitors. In this study, we examined a method of reading text called Menazırü'l-avalim written by Aşı1k Mehmed in the 16th century and the works of Per Minas Bijıskyan's Pontus History and Şakir Şevket's Trabzon History, both of them written in the 19th century. The Trabzon-born Aşık Mehmed (16th century), Minas Bijıskyan (19th century), Şakir Şevket (19th century) and İsmail Safa (19th century) have conveyed information concerning the history, structures, epitaphs, streets, bazaar and mahalles, demographic structure and daily life of the people of the city. Their notes are evaluated and compared and were found to sometimes contradict each other and sometimes match up or complete each other. . The poetic work of İsmail Safa has not been included in the study because it did not give clear information on the urban tissue of the city. Evaluation of the information included in the travelogues is essentially inclined towards understanding the urban tissue of the city. Therefore, texts of these travellers have been discussed with a focus on the location of the city, its harbour and its religious, military, commercial and civil structures which are a part of the city's urban tissue. The information given by these three travellers was collectively evaluated; consequently, it was noted that although Aşık Mehmed and Şakir Şevket predominantly draw attention to Ottoman urban texture, P. Minas Bijış̧ described the same era as that described by Şakir Şevket but with an emphasis on the non-Muslim structures of the Ottoman and pre-Ottoman period. Because travellers narrate their own homeland, they most particularly mention their own experiences beyond mere observation and speculation. However, the era in which these travellers lived and the information about their identity (e.g., religious, political and vocational) can be traced through their texts. Within this context, although travellers have narrated their own homeland through their own life perspective, this has enabled us to reach different stories and question what seems to be correct. Furthermore, they have provided important information with detailed description regarding many structures and locations. This information has been missing and was not mentioned in many sources.
\end{abstract}

Keywords: Travelbook, Trabzon, Aşık Mehmed, Minas Bijıskyan, Şakir Şevket. 


\section{GíRIŞ}

Seyahatnameler, seyyahların gezdikleri yerlerde gördüklerini kaleme aldıkları, o yerin coğrafyası ve iklimi ile birlikte eski-yeni yapılarını, yol-ulaşım özelliklerini ve gündelik hayatın tüm ayrıntılarını konu edinen metinlerdir. Seyyahın; gidip gördüğü yeni yerleri kendi halkına anlatma isteği içinde, zaman-mekan ikilisini tüm detayları ile metne döktüğü, hatta çoğu zaman resmettiği eserler olmaları nedeniyle de hiç kuşkusuz kent tarihi yazımının en çok başvurulan kaynaklarından birini oluştururlar.

17.-18.yy.lardan itibaren Batı dünyasının askeri ve ekonomik yayılımına, bilgiye dayalı bir yayılmacılığın da eşlik etmesiyle birlikte seyyahlar farklı coğrafyalara ve şüphesiz Osmanlı topraklarına yönelmişlerdir. Trabzon kenti de, sahip olduğu coğrafi konum ve ticaret yollarının kavşak noktasında yer alan iskele-pazaryeri niteliğiyle, merak duygusuyla hareket eden birçok seyyahın gezi güzergâhında yerini almıştır. Trabzon'dan geçen tüm seyyahlar kendi bakış açıları ve üslupları ile bir Trabzon panoraması çizmişlerdir. Kentin coğrafi yapısı, ormanları, bitki örtüsü, iklimi ve doğal yaşamı hakkında bilgi vermenin yanında bölgedeki yerleşim yerlerini, ticaretini, yol ve ulaşım durumunu, sosyal hayatını, nüfus ve toplum yapısını merak ederek bunlara dair notlar tutmuşlardır.

Kent tarihi açısından oldukça zengin materyal barındırdıkları şüphesiz olan bu metinlerin, yazarın önyargıları ile gördükleri arasında sıkışıp kaldığını göz ardı etmek ve anlattığ1 yere ilişkin pek çok bilinmeze açıklık getirmiş olduğunu düşünmek yanıltıcı olabilir. Ayrıca bu seyyahların içinde, gördüklerini olduğu şekli ile anlatanlar olduğu gibi, kendinden önceki başka eserlerden doğrudan aktarmalara yer vererek her zaman özgün değil, kimi zaman birbirlerinin varyasyonları şeklinde de olabileceklerini akıldan çıkarmamak gerekir.

Trabzon hakkındaki bilinen en erken yazılı metin MÖ 400'lerde yazılmış olan Ksenophon'un Anabasis'idir¹. Bunun dışındaki erken dönemli olarak tanımlayabileceğimiz diğer üç eser; Yunanlı filozof-tarihçi Arrianos'un Karadeniz Seyahati², Roma İmparatoru Justinianos dönemi imar ve bayındırlık faaliyetlerini anlatan Procopius'un Yapılar' ${ }^{3}$ ve 7.yy.da kenti ziyaret eden coğrafyacı Şiraklı Annians'ın otobiyografisidir'4. İslamiyet'le birlikte Trabzon ve çevresine ilgi gösteren İslam seyyahları arasında ilk akla gelen isim, kendisinin bölgeye gelip gelmediğine dair net bilgilere ulaşmak mümkün olmasa da, 13. yy seyyahlarından İbn-i Bibi5 ile Mesalikü'l-Ebsâr fî Memalikü'l-Emsâr adlı eseri ile İslam tarihçilerinden el-Ömeri'dir ${ }^{6}$. Komnenos Hanedanlığı döneminde yolu Trabzon'dan geçen diğer seyyahlar Friar Odaric 7 , Gonzales de Clavijo 8 (14 Nisan 1404) ve Pero Tafur'dur'. Osmanlı fethinin ardından, 16. yy. Trabzon'undan söz eden tek metin; kendisi de Trabzonlu olan Osmanlı coğrafyacısı Âşık Mehmed'in Menazirü'l- Avalim'idir (Ak, 1990, s. 13-31). Kenti,

\footnotetext{
${ }^{1}$ Kseneophon. (1998). Anabasis Onbinlerin dönüşü, İstanbul: Sosyal Yayınlar.

${ }^{2}$ Arrianus. (2005). Arrianus'un Karadeniz seyahati (Arriani Periplus Ponti euxini) ( M. Arslan, Çev.) İstanbul: Odin.

${ }^{3}$ Procopius. (1940). Procopıus, on buildings, general index (H. B. Dewing, Çev.) Cambridge: Harvard Univ. Press.

${ }^{4}$ Ananias of Širak. (1992). The geography of Ananias of Širak. (R. Hewsen, (Çev.) Wiesbaden.

5̇̉bn-i Bibi. (1996). Selçukname. (M. Öztürk, Çev.) Ankara: T.C. Kültür Bakanlığı Yayınları.

${ }^{6}$ el- Ömeri. (2014). Türkler hakkında gördüklerim ve duyduklarım (Mesaliku'l Ebsar) (A. Batur, (Çev.) İstanbul: Selenge Yayınlar1

7 Odaric, F. (2002). The travels of Friar Odoric. H. Yule (Ed.) Michigan: W.B. Eerdmans Publishing Company.

${ }^{8}$ De Clavijo, R. G. (2016). Timur devrinde Kadis'ten Semerkand'a seyahat (R. Ö. Doğrul, (Çev.) İstanbul: Köprü Kitaplar Yayınevi.

9 Tafur, P. (1926). Travels and adventures (1435-1439). M. Letts (Ed.) Londra: Routledge.
} 
$1609^{\prime}$ da ziyaret eden Julien Bordier' in ${ }^{10}$ izlenimlerini aktardığı metni; günümüze ulaşmamış olan eserler hakkında yaptığı mekânsal tariflerle birlikte, kent yerleşim planı niteliğindeki çizimi ile önemli bir veri kaynağıdır. Aynı yüzyılda Trabzon'un tarihi ve kültürel mirasından bahseden Evliya Çelebi' $\operatorname{nin}^{11}$ seyahatnamesi ile Katip Çelebi'nin Cihannüma's ${ }^{12}$ da sıklıkla başvurulan eserlerdendir. ${ }^{13}$ 18.yy. sonlarında Trabzon'a gelen doğa araştırmacısı Joseph Piton De Tournefort, Levant Yolculuğunun Öyküsü̈14 adlı eserinde, kentin doğal güzelliği, tarihi ve kiliselerinden bahsetmiştir (Usta, 2013, s. 198-213).

19-20.yy.larda sahip olunan siyasal ortam ve Trabzon'un uluslararası bir ticaret limanı haline gelmesiyle, özellikle Avrupa'nın değişik ülkelerinden çok değişik amaçlarla onlarca seyyah Trabzon'a gelerek inceleme ve tespitlerde bulunmuşlardır (Yılmaz, 2006, s. 214). Tek ortak yanları kentin henüz keşfedilmemiş özelliklerini araştırmak olan ziyaretçiler arasında özellikle siyasi görevliler, askerler, konsoloslar, ticaret yolları arayanlar, bitki ve böcek toplayan doğa bilimciler, yerinde araştırma yapan arkeologlar, tarihçiler, coğrafyacılar ve jeologların varlığı dikkat çekicidir. ${ }^{15} \mathrm{Bu}$ dönemde kent hakkında en detaylı bilgi verdiğini söyleyebileceğimiz seyyah P. Minas Bıjışkyan'dır. Kendisi de tıpkı Aşık Mehmed gibi Trabzonlu olan seyyah güney ve kuzey Karadeniz kıyılarını adım adım gezerek, 1817'de doğum yeri olan Trabzon'a gelmiş ve kaleme aldığı Karadeniz Kıyıları Tarih ve Coğrafyası adlı eserinde kente dair oldukça ayrıntılı bilgiler vermiştir. Alman bilgin olan Jakob Philipp Fallmerayer (Trabzon İmparatorluğu Tarihi-1840; Doğu'dan Fragmanlar-1845), William John Hamilton (1836), Fransız hükümeti tarafından görevlendirilen coğrafyacı-bilim insanı Xavier Hommarie de Hell (1838) ve beraberindeki ressam Jules Laurens, William Francis Ainsworth (1840), Joseph Marie Jouannin (1840), Fransiz arkeolog Charles Texier, Alman Carl Koch, George Finlay, C. Stuart, F. Walpole, Heinrich Barth, Dr. O. Blau, Théophile Deyrolle, İngiliz Konsolosu W. G. Palgrave, sonraki konsolos Alfred Biliotti, Henry Fanshawe Tozer, Edmunda Naumann ve H. F. B. Lynch bu tarihten itibaren bölgeye gelen, özellikle Trabzon hakkında ayrıntılı bilgiler aktaran gezginleridir.

Trabzon kentini çeşitli sebeplerle ziyaret eden ve kente dair gözlemlerini kaleme alan çok sayıda seyyahın varlığı dikkat çekicidir. Bu durum akla çalışmanın da ana temasını oluşturan şu soruyu getirmektedir. Kenti ziyaret eden Osmanlı içinden veya dışından kente yabancı bir seyyah ile Trabzonlu yani kenti memleketini anlatan seyyahların verdikleri bilgi arasında fark var mıdır? Bu farklılık herhangi bir çelişki olabileceği gibi, hiç değinilmeyen kente yabancı bir seyyah için önemsiz görünen bir detayda (yapı, yol, mahalle vb.) olabilir. Kentin kaleme alınan uzun tarihi açısından, seyyah(lar) ele alınarak şüphesiz pek çok değerlendirme yapılabilir. Ancak bu çalışmada araştırma amacı Trabzon kentini yine Trabzonlu olan seyyahların metinleri üzerinden anlamaya çalışmaktır. Bu nedenle yaşadığı kenti/memleketini seyahatnamesinde anlatan seyyahların aktardıkları bilgiler birbirleri ile ne kadar örtüşmektedir? Bu seyyahların aktardıkları bilgiler birlikte ele alındığında ne kadar eksiksiz bir kent dokusu ortaya konulabilir? sorularına da çalışma kapsamında cevap aranacaktır.

\footnotetext{
${ }^{10}$ Bordier, J. (1935). Relation d'un voyage en Orient. Atina: Hestia.

${ }^{11}$ Çelebi, E. (2008). Günümüz Türkçesiyle Evliya Çelebi seyahatnamesi: Bursa-BoluTrabzon-Erzurum-Azerbaycan-KafkasyaKırım-Girit. Y. Dağlı ve S. A. Kahraman, (haz.) İstanbul: Yapı Kredi Yayınları.

${ }^{12}$ Çelebi, K. (2010). Cihannüma. S. Öztürk ve B. Karlıăga (haz.) İstanbul: İstanbul Büyükşehir Belediyesi Yayınları

${ }^{13}$ Bu eserlerde yer alan Trabzon kenti ile ilgili derli toplu bilgi için bknz: Usta (1999).

${ }^{14}$ Tournefort, J. D. (2005). Tournefort seyahatnamesi, (Z. Kılıç, Çev.) İstanbul: Kitap Yayınevi.

${ }^{15}$ Seyyahlar için detaylı çalışma için bknz: Y1lmaz $(2006$; 2015).
} 


\section{TRABZON'LU SEYYAHLAR: YAŞAMLARI VE ESERLERI}

Aşık Mehmed (16. Yüzyıl): Mehmet b. Ömer b. Bayezid el-Aşık yani Aşık Mehmed Bin Ömer, 1556 yılında Trabzon'da Tekfur Saray Mahallesi'nde, bugünkü Erdoğdu Mahallesi sınırları içinde doğmuştur. Babası Ömer Bin Bayezid, yine sur dışında yer alan Tekfur Saray Mahallesi'nden, annesi ise Ortahisar Mahallesi'ndendir. Annesi hakkında daha fazla bilgi bulunmamakla birlikte babasının İmaret-i Hatuniye'nin (Gülbahar Hatun Camii) bugün yıkılmış olan darü'l-kurrasında Kuran öğretmeni olduğu bilinmektedir (Ak, 1990, s. 8-9). Aşık Mehmed, 20 yaşına kadar Trabzon'da Fatih Medresesi, Hatuniye Medresesi ve İskender Paşa Medresesi'nde eğitim almış, bu eğitimi sırasında tarihi kaynakları ve edebi eserleri inceleyerek kendisini yetiştirmiştir (Ak, 1990, s. 11-12). 20 yaşından sonra ise yeni yerler görmek ve yeni eğitimler almak amacıyla birlikte Trabzon kentinden ayrılarak 22 yıl sürecek seyahatine başlamıştır (Usta, 1999, s. 35). Hangi güzergahı takip ettiğine dair net bilgiler olmasa da seyahatnamesi olan Menazırü'l-avalim'de karışık olarak nereye gittiği ve ne kadar süre kaldığı bilgisini aktarmıştır. Aşık Mehmed, Trabzon'da yaşayan Rumlardan öğrendiği Rumca ve medresede öğrendiği Arapça ve Farsça dilleri sayesinde farklı etnik kökendeki insanlarla iletişime geçebilmiş, farklı dillerde ki edebi eserleri okumuştur (Ak, 1990, s. 13-14).

16.yy'da kaleme alınmış en önemli coğrafya eseri olarak tanımlayabileceğimiz Menazırü'l-avalim'de16; Macaristan, Kırım, Kahire, Şam, özellikle Rumeli ve Doğu Avrupa'nın yer aldığı geniş bir coğrafya anlatılmaktadır (Usta, 1999, s. 35; Aydın, 2012, s. 445). 1596 yılında yazmaya başladığı seyahatnamesini, beş ay ara vererek 1597 yılında tamamlayan (Ak, 1990, s. 50) Aşık Mehmed eserinde, gezip incelediği yerlere dair gözlemleri ile birlikte Ortaçağ'a ait Arapça-Farsça eserler ve Osmanlı dönemi yazılı kaynakları ile birlikte çeşitli sözlü kaynaklardan edindiği bilgileri de aktarmıştır. Seyahatname, ismini tam anlamiyla yansıtmakta ve "Menazırü'l-avalim" yani alemden manzaralar sunarak kentlerin yerleşim şekillerini ve mimari eserleri hakkında önemli bilgiler vermektedir. Ayrıca eserde şehirlerin mekansal özellikleri dışında bitkiler, madenler ve hayvanlar konusunda da bilgiler verilmektedir. Menazırü'l-avalim'in en önemli özelliği, Aşık Mehmed'in gezip gördüğü yerleri anlatırken, onları coğrafi sistem içinde anlatmasıdır. İklim-i örfi olarak isimlendirilen ve gece-gündüz uzunluklarına dayanan bu sistem bahsi geçen yerin, hangi enlemde olduğunu belirlenmesine imkan vermektedir (Ak, 1990, s. 67).

Per Minas Bıjışkyan (19. Yüzyıl): Per Minas Bijışkyan, 1777 yılında Trabzon'da doğmuştur. 1804 yılında rahip unvanıla Venedik Mikhitarist Kongregasyonu'na katılmak amacıyla kentten ayrılmış ve Venedik'e gitmiştir. Görevi nedeniyle (Vikerlik-papaz) 18171819 yılları arasında zaten yerlisi olduğu Karadeniz'in kuzey ve güney kıyılarını ziyaret etmiştir. 1851 yılına kadar sürdürdüğü inceleme amaçlı seyahatleri ile öğretim, dil, tarih ve coğrafya alanlarında eserler oluşturmuştur (Bijıskyan, 1998, s. 11-13).

Bijıssyan (1998, s. 92), MÖ 4.yy'da ordusuyla birlikte Karadeniz'den geçen Ksenofon'un ve Arrianos'un bizzat gördüklerini aktardıklarını, fakat daha sonraki zamanlarda bazı Avrupalı seyyahların bölgeyi tehlikeli görerek, kenti görmeden yazdıklarını belirtir, bu durumu önemli bir eksiklik olarak dile getirir. Bu nedenle Karadeniz kıyılarını boydan boya gezerek, gördüklerini aktardığı Pontus Tarihi isimli eserinde; gördüğü yerlerin coğrafyası, tarihi, etnografyası ve topografyası hakkında önemli bilgiler vermiş,

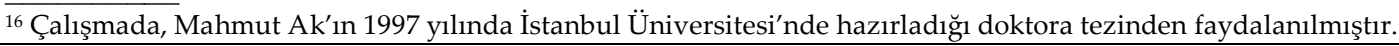
SEFAD, 2020; (43): 435-466 
mekanları ölçüleri ile tanımlayarak, yapıların kitabelerini ve kiliselerdeki yazmaları okumuş ve kaydetmeye çalışmıştır. Pontus Tarihi'nde, en eski çağlardan 19.yy'ın başlarına kadar yaşayan kavimler hakkında ve zamanla yok olmuş veya mevcut şehirlerin, devletlerin, zamanla değişen etnografik vaziyetleri hakkında birçok eski yazılarla kendi gözlemlerini kıyaslayarak aktarmıştır (Bijışkyan, 1998, s. 11-13).

Şakir Şevket (19. Yüzyıl): Şakir Şevket, 1847 yılında Trabzon'un Ortahisar'da Cami-i Kebir Mahallesi'nde (Ortahisar Fatih Camii'nin tanımladığı mahalle) dünyaya gelmiştir. Şakir Şevket'in babası, ticaretle uğraşan Yemenici Mehmet Efendi'dir. Kişiliğini ve düşünce yapısını şekillendiren eğitim hayatı sırasında dönemin alimlerinden olan Hacı Fehmi Efendi'den Arapça ve Farsça dersleri almıştır. Ayrıca eğitimine devam ettiği Ortahisar Saray-ı Atik Mahallesi'ndeki selamlığında ${ }^{17}$ da Trabzon'un ilim, kültür ve sanat alanındaki önemli simalarıyla karşılaşmıştır. Eğitim ile eş zamanlı baba mesleği olan ticaret işini de yürütmüştür. Daha sonra devlet memurluğunda görevler üstlenmiş; ilk olarak Trabzon Vilayeti İdare Meclisi'nde daha sonra ise Meclis-i İdare-i Vilayet Katib-i olarak çalışmıştır. Görevleri esnasında gözlerinden rahatsızlanan Şakir Şevket Trabzon'dan ayrılarak İstanbul'a taşınmıştır. Burada kaldığı sürede gazetelerde yazarlık yapan Şakir Şevket, Trabzon Valiliği'ne atanan Müşir Ahmed Rasim Paşa tarafından tekrardan Trabzon'a geri getirilmiş ve Vilayet Gazetesi başyazarlığına ve Mektubi Kalemi Mümeyyizliğine (Yazı işleri memurluğu) tayin edilmiştir. Aynı zamanda Trabzon Askeri İdadisi'nde de hocalık yapmıştır. (Şevket, 2001, s. 12-16).

Şakir Şevket, diğer seyyahlar gibi Trabzon üzerine bir seyahat gerçekleştirmemiştir. Trabzon'da doğup büyüyen Şakir Şevket, Trabzon'un mekanlarını, nüfusunu, yaşam biçimi ile birlikte Trabzon merkez yönetiminde kimlerin ne görevler yaptığını hangi tarihi kişilerin Trabzon'da bulunduğu gibi konulara da değinerek bir nevi siyasi bir metin kalem aldığ söylenebilir.

İsmail Safa (19. Yüzyıl): İsmail Safa, Trabzonlu babası Mehmet Behçet'in Hicaz Vilayeti Mektupçusu görevi zamanında 9 Mart 1867 yılında Mekke'de Safa ve Merve arasındaki Mesa Mahallesinde doğmuştur (Usta, 1999, s. 179; Çelik 2017, s. 3). İsmail Safa 7 yaşında, annesi Ayşe Samia Hanım'ı ardından 13 yaşında babasını kaybedince kardeşleriyle birlikte İstanbul'a gelmiş ve İstanbul'da Darüşafaka'da eğitime başlamıştır. Eğitimi sırasında Arapça ve Farsça sonrasında ise Fransızca öğrenmiştir. Babası Mehmet Behçet gibi şair olan İsmail Safa, henüz daha eğitim gördüğü dönemde şiirlerini yazmaya başladığı bilinmektedir (Çelik, 2017, s. 5-6, 8). 1891 yılında babasının doğup büyüdüğü yerleri görmek amacıyla Trabzon'a doğru yola çıkan İsmail Safa duygu ve düşüncelerini Mevlid-i Pederi Ziyaret adlı şiirinde kaleme almıştır. İsmail Safa'nın bu eseri, Trabzon'un olduğu kadar belki de Türk edebiyatının kaydettiği ilk ve tek manzum seyahatnamedir (Usta, 1999, s. 179).

İsmail Safa'nın deneyimlerini ve duygularını anlattığı seyahatnamesi beyitlerden oluşmaktadır. Seyahatname, seyyahın Trabzon'a çıktı̆̆ gemi yolculuğunu anlatmasıyla başlamaktadır ve gemideki deneyimlerini anlatırken bir yandan da Trabzon'un vadilerine, dağlarına, denizine vb. coğrafi unsurlarına genel göndermeler bulunmaktadır. Trabzon'a ulaşan İsmail Safa, babasının doğup büyüdüğü evi bularak orada yaşadığı duyguları dile getirirken babasının komşusu olan bir ziyaretçiyle tanışarak aralarında geçen konuşmayı

17 Şehrin yüksek tabakasındaki insanlar vakit geçirmek amacıyla konakların selamlıklarında toplanırdı. Toplantılarda memleketin çeşitli meseleleri ile birlikte, ilmi ve edebi konular konuşulurdu. Buralar bir bakıma akademi görevi görürlerdi. 
aktarmaktadır. Daha sonrasında ise doğuya doğru giderek Trabzon kentinden ayrılmaktadır. İsmail Safa diğer seyyahlar gibi Trabzon kenti hakkında net bilgiler vermediği görülmektedir.

\section{MEMLEKETINII ANLATAN SEYYAHLARIN KALEMINDEN TRABZON}

\section{Trabzon İsminin Kaynağı}

İsmine ilk kez MÖ.400'de bölgeye gelen Ksenophon'un (1998) Anabasis adlı eserinde "Trapezus" olarak rastladığımız kentin adının kökeni hakkında sayısız görüş bulunmaktadır. Nitekim Trabzonlu seyyahların her biri de ismin kaynağına dair birden fazla ve farklı tanımlamalar yapmışlardır.

Aşık Mehmed (Ak, 1997, s. 404), bazı şiirlerden yola çıarak isminin "Tarabefzun" olduğunu belirtmektedir. Bunun yanında İbn Said'in bilgilerinden de yararlanarak Trabzon isminin eskiden "Tarabzende" olduğundan söz etmektedir. Minas Bijışkyan'da (1998, s. 90-91, 99), Aşık Mehmed gibi eski kaynaklardan ve kendi gözlemlerinden yararlanır; kentin isminin "Trapeza" veya "Trapezon" olarak anıldığını, bu ismin kaynağının da sahip olduğu eski kalesi olduğunu vurgular. Hatta Türklerin Trapezon kelimesinin anlamını bilmediklerini, Grek askerlerinin bozguna uğramasına atıfta bulunarak Trapezon ismini "Tabur Bozan" şeklinde yanlış ifade ettiklerini belirtir. Şakir Şevket (2001, s. 47-49) ise isim hakkında bazı rivayetler olduğunu söyler. Bu rivayetlerden ilkini öncelerden inşa edilen "kal'a" (kale) binasının daha sonrasında büyük hisarlar arasında kalarak sofraya benzediğini ve bu nedenle buraya "Trabzon" denildi şeklinde aktarır. İkinci rivayette göre ise Trabzon'da sofra şeklinde birçok büyük taşların görüldügünü, Yunancada sofraya trapeza denildiğinden buraya "Trabzan" ismi verilmiş olduğunu söyler. Kendisi ise ikinci rivayetin gerçeği daha fazla yansıttığına inanmaktadır. Ancak metnin ilerleyen kısımlarında ise şehrin adı hakkında halk tarafından söylenildiğini belirttiği ve "tuhaf" olarak başlıklandırdığı iki rivayetten daha bahseder. İsmin kaynağı Köroğlu gibi bir kahramandır. Bu kahraman kente gelerek yiğitliğini halka göstermek amacıyla sikkenin tuğrasını parmağıyla bozar ve kendisine daha sonra kentin ismini de oluşturan "Tuğra-bozan" ismi verilir. Ayrıca metinde günümüzde kullanılan Trabzon kelimesinin Acemlerin idaresi zamanında kullanılan "Tarabefzun" isminin değiştirilmiş hali olduğunu da belirtir.

\section{Kentin Coğrafyası ve İlk Yerleşim}

Trabzon kenti, bulunduğu coğrafik ve jeopolitik konumu nedeniyle tarih boyunca farklı medeniyetlerin ilgisini çekmiş, her birinin geride bıraktığı izlerle birlikte birinden ötekine yaşanan fiziksel değişimin derinlemesine gözlendiği kadim yerleşimlerden birisi olmuştur. Trabzon'un ilk yerleşimciler için, güvenlikli topografik yapısı ve bu topografyanın denizle kurduğu ilişkisi nedeniyle olağanüstü bir yerleşim alanı olarak görüldüğü açıktır. Kentin ilk kurulduğu bölgenin iki derin vadi arasında, savunulabilir ve yerleşime uygun bir plato özelliği göstermesi bunun en açık göstergesidir (Üstün Demirkaya ve Tuluk, 2018, s. 714). Kentin kuruluş tarihi olarak Eusebius'un MÖ.756 (Miller, 2007, s. 8) tarihi kabul görmekle birlikte bu tarihi kesinleştirecek herhangi bir belge/arkeolojik veri bulunmamaktadır. Nitekim Texier (2002, s. 154), kuruluş tarihinin MÖ.2000'ler olması gerektiğini ve Eusebius'un tarihlendirmede kullandığı Miletosluların kente gelişinden önce burada bir halkın oturmakta olduğunu söylemektedir. Bu bağlamda kentin kuruluşunun tarihlendirilmesinde farklı birçok görüş bulunmaktadır. 
Bijışkyan (1998, s. 89), metninde çeşitli kaynaklara atıfta bulunarak Trabzon kentinin Kral Ezakya zamanında 2536 yıl önce kurulduğunu ya da Roma'nın kuruluşundan 5 yıl önce Kral Yoatam tarafından kurulduğunu belirtir. Şakir Şevket'te (2001, s. 44-46) yakın bir tarih vererek, kentin yaklaşık olarak yazdığı eserden 2626 sene önce, Sinob Sancağı'nı oluşturan Yunanîler tarafından kurulduğunu belirtmektedir. Eserin yayınladığı tarih olan 1877 senesi dikkate alındığında, Şakir Şevket'in kentin kuruluş tarihi olarak MÖ 746 senesine işaret ettiği anlaşılmaktadır. Nitekim metnin başka bir bölümünde de Trabzon'un Roma'dan ve İstanbul'dan önce MÖ. 750'lerde Miletos şehri ahalisinden İskiris tarafından kurulduğunu söyler. Şakir Şevket'in kentin kuruluşuna, metnin bir bölümünde vermiş olduğu Sinop tarafından, bir bölümün de ise Miletliler tarafından bilgisi aslında aynı ifadenin farklı betimlenmiş hali olduğu söylenebilir.

Aşık Mehmed (Ak, 1997, s. 404-405) kentin konumuna ilişkin, genelden özele, kente komşu yerleşim birimleri ve kentin ilçelerini tanımlar. Seyyahın belirttiğine göre Trabzon, "17. Ikklimi örfi" olan Rum şehirlerinden biridir. Fakat Aşık Mehmed (Ak, 1997, s. 404) bunun yanında, Ebü'l-Fida'nın Takvîmü'l-büldân eserinde Trabzon'un, 18. İklimi örfi olan Erminiyye, Erran ve Azerbaycan cetvelini tamamlamak üzere burada yer alan ve Anadolu'ya açılan bir iskele olduğuna dair bilgi verdiğini belirtir. Kentin çevresinde yer alan komşu yerleşmeleri; güney doğuda Legzi Dağlar1 ${ }^{18}$, güneybatıda Çepni Dağları olarak isimlendirdiği dağlar, batıda Trabzon'a üç günlük mesafede tanımladığı ve bugün Abhazya Cumhuriyeti sınırları içinde yer alan Sohum, dört günlük mesafede Abhas (Abhazya) olarak sıralar. Şakir Şevket (2001, s. 79) ise kentin sınırlarını, Rusya'nın Kafkasya kısmında deniz kıyısında, doğudan Erzurum, güneyde Erzurum ve Sivas, batıda Kastamonu ile çizer. Kentin kurulduğu alanı şehrin kırk bir derece kuzeyinde yirmi beş dakika doğusunda, denize kadar uzanan Boztepe dağı eteklerinde tanımlar. Bijışkyan (1998, s. 81) Trabzon'u ilçeleri ile tanımlar. Batısında; 9 mil (yaklaşık 17,2km) ${ }^{19}$ kadar uzaklıkta, bugünde aynı isimle bilinen Yoros koyunun içinde Plata/"Platana" bugünkü Akçaabat, doğuda; Çömlekçiden 6 mil $(11,5 \mathrm{~km})$ uzaklıktaki yazlık bir liman olan günümüzde Yomra ilçesine bağlı Kaşüstü Mahallesi yakınlarındaki Kovata, Kovata'nın 18 mil (yaklaşık 34,5km) uzağında yine kışın birçok geminin demir atabilmesi için uygun bir liman olan Sürmene yer alır.

\section{Kentin Osmanlı Fethi}

Anadolu kentleri açısından her zaman önemli bir pazar ve transit ticaret merkezi olan Trabzon, Osmanlıların Balkanlar ve Karadeniz'e açılma stratejisinin gereği olarak Fatih Sultan Mehmed tarafından 1461'de fethedilmiştir (Aygün, 2005, s. 13). Ancak Trabzon'un fethinin hangi ay ve günde yapıldığı konusunda kaynaklarda kesin bir bilgi bulunmamaktadır. Bijıskyan (1998, s. 91-92) ve Şakir Şevket (2001, s. 67-75); 1461 y1lında Fatih Sultan Mehmed'in on iki gün süren kuşatması sonucunda Trabzon'u fethettiğini belirtirler. Aşık Mehmed (Ak, 1997, s. 405), kaynak olarak Mehmed B. Ramazan'ın etTevki'i'nin Tevarih-i Al-i Osman'ını göstererek, kentin fethinin yedinci Osmanlı padişahı tarafından H.865 (1460/61) yılında gerçekleştirildiğini söyler. Şakir Şevket fethi diğer seyyahlara göre daha detaylı bir şekilde aktarır; İstanbul'un ardından Trabzon'un fethedilmesi Fatih Sultan Mehmet tarafından önemli görülerek, bu amaç doğrultusunda yapılan siyasi-askeri hareketler ve hazırlıklar sonrasında kentin “Hicri 866 yılının Ağustos

\footnotetext{
18 İbn Said'i kaynak göstererek Trabzon ahalisinin çoğunu Legzilerin ${ }^{18}$ oluşturduğunu belirtmektedir. Seyyah Lezgi kelimesinin zamanla değişime uğrayarak bugün kullanılan "Laz" biçime geldiğini söylemektedir.

19 "Mil" in metrik değerleri olarak 1920-1940 metre aralığ1 esas alınmıştır.
} 
ayının onbeşinci gününde" (15 Ağustos 1461) fethedildiği belirtir. Kenti ele geçirip, genel hakimiyeti sağladıktan sonra, kesin hakimiyeti sağlamak için uygulanan Osmanlı fetih politikası gereği, Aşık Mehmed'in (Ak, 1997, s. 405) de belirttiği gibi kale içerisinde yaşayan ve kentin ileri gelenleri Trabzon'dan çıkarılmış, geriye alt tabakada yer alan gayrimüslimler kalmış ve onlarda kale içerisinden çıkarılarak Meydan-i Şarki (Gavur Meydanı), Ayafilibo ve Yeni Cuma mahallelerine yerleştirilmişlerdir. Fatih Sultan Mehmet tarafından fetih öncesi ve fetih sırasında tahrip olan Trabzon Kalesi ile birlikte "Altunbaş Kilisesi" (Ortahisar Fatih Camii) ve Ayasofya Kilisesi tamir ettirilmiştir.

\section{Trabzon Kentinde Surlar ve Savunma}

Kent binlerce yıl süren yaşamını doğu ve batısında yer alan derin iki vadi boyunca yükselen sur duvarlarına borçludur. Bu surlar tarihin her döneminde olduğu gibi günümüzde de kentin fiziksel ve tarihsel çeperlerini belirlemektedir. Bu sur sisteminin planını ise arazinin doğal yapısı, savunma zorunlulukları belirlemiştir (Üstün Demirkaya, 2014, s. 59). Şakir Şevket'inde (2001, s. 54, 122) ifade ettiği gibi bu surlarla çevrili alan zamanla kuzeye, denize doğru genişlemiş ve günümüzde bulunmayan ancak bugünkü Moloz'da varlığı bilinen limana kadar uzanmıştır.

Trabzon kentinin iki surdan ve bir kaleden oluştuğuna değinen Aşık Mehmed (Ak, 1997, s. 405-406), surların halk tarafından Ortahisar ve Aşağıhisar olarak adlandırıldığını ve bugünkü Yukarıhisar veya İçkaleye'de Kule denildiğini aktarır. Bijışkyan (1998, s. 89, 99), Trabzon Kalesi'ni bir tepe üstünde uzunca ve dört köşe şeklinde biçime sahip olduğunu, kuzeyden güneye doğru Boztepe dağına kadar uzandığını belirtir. Biçimleri, birbirleri ile kurdukları ilişki nedeniyle genel görünümünü bir tavus kuşuna benzettiği surları kuzeyden güneye; en genişi olan Aşağıhisar, kuşun açılmış kuyruğu gibi Ortahisar'a kadar yayılmış, batı tarafta, biraz içeriye çekilmiş olan Ortahisar, kuşun gövdesini; aynı zamanda Kulehisar olarak da adlandırdığı İçkale, boynunu, eğri vaziyette son kısmı olan kule de başı şeklinde tasvir eder. Surlar, kentin tarih boyunca geçirdiği çeşitli saldırı ve işgaller neticesinde sürekli tahrip edilmiş, imparatorlar tarafından sürekli onarılmış, güçlendirilmiş, yeni eklerle genişletilmiştir. Bijışkyan'da (1998, s. 92) eski kaynaklardan edindiği bilgilere dayanarak, mevcut kalenin daha eski bir kalenin üzerine inşa edildiğini, bu eski kalenin surlarının da iki kat olduğunu belirtir. Ancak eski kale üzerine inşa edilen kısmından bahsederken, mevcutta üç bölümden oluşan sur sisteminin tümünden mi yoksa bir bölümünden mi bahsettiğini açıklamaz. Çoğu yerde kaya üzerine inşa edilmiş, derin ve geniş hendeklerle çevrili surların zaman içerisinde çok değiştiğini, günümüze ulaşabilmesinin ise pek çok kralın yaptırdığı ilaveler ve tamirlerin neticesi olduğuna vurgu yapar.

Yukarhhisar Surlar//Kale/Kule: Kentin güney ucunda, diğer iki hisardan daha yüksek konumda ki Yukarıhisar kentin ilk yerleşim alanıdır. Doğuda Tabakhane, batıda ise Zağnos derelerinin oluşturduğu iki derin vadi arasında, güneyde yüksek kaya kitlesi üzerinde inşa edilmiştir. Aşık Mehmed (Ak, 1997, s. 406), diğer kayıtlarda Yukarıhisar veya İçkale olarak anılan bu bölümden Kule olarak bahseder ve bekçi-muhafızlar tarafından korunan müstahkem bir kale olarak tanımlar. Kulenin içerisinde Cuma namazı kılınabilen bir caminin yer aldığını da belirttikten sonra "Kule"nin kapılarından bahseder. Aşık Mehmed'e (Ak, 1997, s. 406) göre Kale'nin iki kapısı vardır; kuzeyinde yer alan kapısı Ortahisar'a açılmakta iken güneyde yer alan ve dışarı açlan tek kapısı kilitli ve gerekli görüldügüunde açılır. Bijışkyan güneyde kentin dışına açılan bu tek kapıyı Kule Kapısı olarak isimlendirir. Ancak Aşık Mehmed (Ak, 1997, s. 406) bu kapının kapalı olduğunu belirtmesine karşın 
Bijıskyan (1998, s. 93) bu güney kapısından Kızgın Dere'ye ${ }^{20}$ inildiğini aktarır. Bölge hakkında en kapsamlı bilgiler Minas Bijıskyan'ın kaleminindendir: Kentin en yüksek yerinde olduğundan "Yukarı Kale" olarak da bahsettiği surlar ile kapsadığı bölgenin Boztepe'nin batı tarafından başlayarak İçkale'ye kadar uzandığını söyler. Kuleboyu denilen geniş ovada yer alan hisarın ucu dardır. Dolambaçlı yollarla birbiri içine girmiş duvarların geniş ve aralarında hendeklerin bulunduğunu, bu bölgede konut bulunmazken, hendeklerden hemen sonra aşağıda konutlar başladığını belirtir (Bijışkyan, 1998, s. 92-93). Bu alanın Bijiskyan'ın metnini kaleme aldığı dönemde silah deposu olarak kullanıldığı anlaşılırken, seyyah buranın asıl işlevinin İmparator tahtının merkezi olduğunu belirtir. Kule'nin alt kısmında kalenin eskiliğini gösteren mağara tarzı mahzenler, surun içinde de yer yer mihraba benzer oyuklar, dolaba benzer şeylerin bulunduğunu, Kule'nin üst kısmı yüksekte olduğu için çift merdivenle çıkıldığını ve burada top atışı yapılan dört köşe büyük bir kulenin yer aldığını ifade eder (Bijışkyan, 1998, 92). Şakir Şevket'te (2001, s. 122) kentin, Osmanlı kaynaklarında Kule Mahallesi olarak geçen, "birkaç taş" ile çevrili olarak tanımladığı bölgede kurulduğunu belirtir. Bu alanda, muhtemelen Bijışkyan'ın "top atışı yapılan dört köşe" olarak tanımladığı kuleden bahsederek, kireçsiz taşlardan kule yaptırıldığını söyler.

Ortahisar Surları: Güneyden kuzeye doğru inşa edilen surların ikincisi olan Ortahisar surları; sivil yapıları, kuleleri, köprüleri ve bunların arasındaki dini yapıları ile kentin eski yerleşim alanının çeperlerini belirlemektedir. Aşık Mehmed (Ak, 1997, s. 406), Ortahisar'ın uzunlamasına bir sur olduğuna değinirken Bijışkyan (1998, s. 93), Aşık Mehmed'e ekler yaparak Ortahisar'ın neredeyse İçkalenin devamı olduğunu ve düz bir mevkide yer aldığını söyler. Seyyahlar, Yukarıhisar ile kıyaslandığında, surların biçimlenişi ve tanımladığı bölge hakkında göreceli olarak daha az bilgi vermelerine karşın, Ortahisar surlarının kapıları hakkında oldukça detaylı bilgiler aktarırlar. Nitekim sur kapıları yalnızca Trabzon'lu seyyahların değil kenti ziyaret eden seyyahların büyük çoğunluğunun ${ }^{21}$ ilgisini çekmiştir. Aşık Mehmed (Ak, 1997, s. 406), kapıların isimlerini Bab-ı Yeni Cuma, Ortahisar'a ait tek

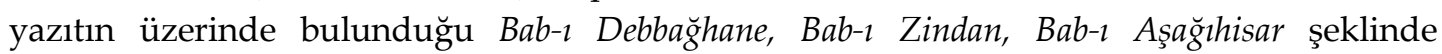
verirken, yerlerine ve özelliklerine ilişkin açıklamalar da yapar. Kent tahkimatının en zayıf noktasını oluşturan, sur duvarlarının yüzeyine açılmış birer geçit olan kapıların, giriş ve çıkışı sağlamaktan çok daha fazlasını üstlendikleri açıktır. Sur içi ile dışını ilişkilendiren, ilgili bölgeleri birbirine bağlayan dahası kentin gelişim yönünü belirledikleri, seyyahlarında betimlemelerinden anlaşılmaktadır. Aşık Mehmed'e göre (Ak, 1997, s. 406), Bab-1 Yeni Cuma'nın Kule olarak bilinen kalenin Ortahisar'a açılan kapısı yakınındadır. Bab-ı Debbağhane Ortahisar'ın doğu duvarının sonundadır ve Tabaklar çarşısı ve debbağhaneler bu kapının dışında olduğundan bu isimle anıldığı, önünde de suyu "büyük vadi" olarak nitelendirdiği Tabakhane Vadisi'nden gelen, küçük bir nehir bu nehrin üzerinde taştan yapılmış “büyük bir köprü” (Tabakhane Köprüsü) bulunmaktadır. Bab-1 Zindan ise surun batı duvarının sonundadır ve sur duvarında yer alan Trabzon kentinin hapishanesine de bu kapıdan geçilerek ulaşılmaktadır. Bab-ı Zindan kapısının önünde de Bab-ı Debbağhane'nin önünde olduğu gibi nehir yer almaktadır. Bu nehir taştan ve ahşaptan yapılmış uzun bir

\footnotetext{
${ }^{20}$ Metinde Kızgın Dere (Bijışkyan, 1998, s. 93) olarak geçen bu yer yine metinde sıklıkla kullanılan, günümüzde de aynı isimle bilinen Kuzgun Dere olmalıdır.

${ }^{21}$ Sur kapılarından detaylı denilecek şekilde bahseden seyyahların bir kısmı; Clavijo, Evliya Çelebi, Joseph Piton de Tournefort, William Hamilton, Karl Koch ve Charles Texier'dir. Ancak metne konu seyyahlardan Şakir Şevket, diğer iki seyyahın aksine, Yukarıhisar surları dışında, surlar ve kapılarından doğruca bahsetmez.
} 
köprü ile geçilerek Aşağıhisar'a ait olarak ifade edilen Bab-1 Zağanos'a bağlanmaktadır. Trabzon hapishanesi de bu kapı üzerinde sur duvarındadır ve bu kapının dışında da büyük vadiden gelen nehir akar. Bab-ı Aşağıhisar ise surun kuzey duvarındadır ve Aşağıhisar'a açılır. Bijışkyan (1998, s. 96, 99-100), Aşık Mehmed kadar detaylı olmasa da kapıların isimleri ve yerlerine ilişkin benzer bilgileri aktarır ve Aşık Mehmed'e ek olarak, muhtemelen savunma sisteminin en zayıf noktaları olduklarından, bütün kapıların çift ve kulelerle desteklenmiş olduğunu ifade eder.

Aşağıhisar Surları: Denize doğru genişleyen sur içi bölgesinin en kuzeydeki bölümü olan Aşağıhisar, Ortahisar'ın kuzey dış suru ile deniz arasındaki boşluğu doldurmaktadır. II. Aleksios Komnenos (1280) döneminde inşa edilen surlara duyulan ihtiyaca yönelik Şakir Şevket (2001, s. 54), Karadenizin dalgalarından şehrin kıyılarını korumak amacı güdüldügünü, bu nedenle Eksütha (Eksotka) civarından Mumhaneönü Mahallesi'ne kadar Aşahisar surlarının inşa edildiğini belirtir. Aşağıhisarın surlarının kare şeklini aldığını ve kuzey surlarının bazı kısımlarının denizle bitişik olduğu belirtir. Bıjışkyan (1998, s. 98), içerisinde evler, çarşı, han, çeşme, cami, medrese ve hamam ile batı ucunda da cephanelikle dolu bir şapel bulunan Aşağıhisar bölgesinin kuzey-deniz tarafından 300 adım²2 (yaklaşık 227m.) genişliğinde, sur duvar kalınlığının ise yer yer 12 adımdan (yaklaşık 9m.) fazla olduğunu belirtir. Aşık Mehmed (Ak, 1997, s. 406) ve Bijıskyan (1998, s. 98-100), Aşağıhisar'ın da Ortahisar gibi dört adet kapısı olduğunu belirtirler ve bu kapıları: Bab-ı Zağnos, Bab-ı Sutha, Bab-ı Moloz, Bab-ı Mumhane şeklinde isimlendirirler. Batıda ki kapı Zağnos Kapısıdır. Bıjıskyan'ın (1998, s. 99) da tasvir ettiği gibi; Ortahisar kapılarından olan Bab-ı Zindan kapısının önünden akan derenin üzerinde yer alan ve Zağnos Kapısı'na uzanan köprü ve bu köprüye bitişik sur duvarı Aşağıhisarın güney duvarını oluşturur. Bijışkyan (1998, s. 99-100), Bab-1 Zağnos'un çift olduğunu belirtir ve diğerini İmaret Kapısı olarak isimlendirir. Hemen karşında yer alan İmaret/Hatuniye Külliyesi nedeniyle bu ismi aldığı düşünülebileceğimiz İmaret Kapısının yanında dört köşe büyük bir kulenin yer aldığını belirtilmektedir. Ancak surun yüksekliğinden dolayı sadece "Bu kuleyi Aleksios Komnenos yaptırmıştır" ifadesi okuyabildiğini söyler. Kapıların ikincisi ise kenti batı varoşlarına bağlayan, denize yakın konumdaki, Aşık Mehmed'e (Ak, 1997, s. 406) göre ismini gayrimüslimlerin yaşadığı Sutha Mahallesi'nden alan Sutha/Sotka kapısıdır. Bıjışkyan (1998, s. 98), Aşağıhisarın batı duvarını; kaleden ayrılmış ve eğri olmasına karşın suru, duvar örgüsünün birbirine kenetli bir şekilde örülen taşlardan oluşması nedeniyle sağlam olarak tanımlar. En kuzeyde, denize bitişik konumda, Moloz Kapısı bulunmaktadır. Muhtemelen hemen deniz kıyısındaki yer alan kapının, denizden gelecek tehlikelere açık konumundan dolayı, Bıjışkyan (1998, s. 98) bu kapının önünde denize karşı topların konulduğunu belirtir. Aşağıhisar surlarının önünde, İşkeleboğ Deresi ${ }^{23}$ ve Moloz Kapısı'nın yer aldığı noktada, kışın gemilerin çekildiğini, koyu renkli geniş bir kumluğun yer aldığını söyler. Aşık Mehmed (Ak, 1997, s. 406) kapının deniz ile ilişkili konumundan dolayı geçişler için pek kullanılmadığını belirtse de Bijışkyan (1998, s. 98) buradan Moloz varoşuna ulaşıldığını belirtir. Son kapı olarak Bab-1 Mumhane ifade edilmektedir. Bijıskyan (1998, s. 98) bu kapının, Mumhane ismine ek "Pazar" ismiyle de anıldığını belirtir. Aşık Mehmed (Ak, 1997, s. 406) bu kapının dışında balmumunun işlenmediğini, Şem'hane'nin bu kapının dışında yer

22 Adımın metrik karşılı̆̆ının 75,8 cm. olarak alınmıştır.

23 Bijışkyan (1998, s. 100), Zağnos Köprüsü'nün geçtiği hendek için “içerisinde halkın deyişiyle İşkeleboğ Deresi akmaktadır" ifadesinde yeralan derenin Zağnos Deresi vadisinden akan ancak belediye çalışmaları neticesinde üstü kapatılan dere olduğu anlaşılmaktadır.

SEFAD, 2020; (43): 435-466 
almasından dolayı bu ismin verildiğini açıklamaktadır. Nitekim Trabzon kentinin sanatkârları da bu kapının dışında ve deniz kenarında yer almaktadır. Bijıskyan (1998, s. 98), Aşağıhisar surlarına ilişkin diğer seyyahların bahsetmediği bir yorum yapar. Moloz Kapısı yakınlarında, kalıntılardan ve doğu tarafında yer alan büyük temelden çıkarım yaparak, surlar henüz inşa edilmeden önce bir kulenin bulunduğunu aktarır. Batı surunun ucunda da, gördüğünü belirttiği bir sedden yola çıkarak daha önce başka bir yapının daha bulunduğunu nitekim Sotka Kapısı yakınında da, bu yapı ile ilişkilendirdiği kapı veya pencereye ait kemerlerin görüldüğünü söyler. Fakat benzer ifadeye başka herhangi bir kaynakta rastlanmadığından doğruluğunu tespit etmek mümkün değildir.

\section{Mahalleler ve Kentsel Doku}

Kente ilk yerleşimlerin ne zaman ve ne şekilde olduğu konusunda tam bir bilgiye sahip olamamakla birlikte, birkaç yerleşim yerinin var olduğu ve zaman içinde nüfus ve ticaret ile paralel bir şekilde yeni yerleşim alanlarının kurulması ile kentin genişlediği tahmin edilmektedir. Bijışkyan'ın (1998, s. 92), eskiden Dios ve Herakles tapınaklarının bulunduğu çaya kadar yayılmış olabileceğini belirttiği kent üç sur içi bölgesi ile doğu, batı ve güney varoşlarından ve bu alanlara yayılan mahallerden oluşmaktadır. Nitekim Aşık Mehmed (Ak, 1997, s. 406) ve Bijişkyan'da (1998, s. 102) kuzeyde denizin olmasından dolay1 kalenin doğu, batı, güney taraflarında varoş adı verilen büyük yerleşim yerlerinin olduğunu ifade etmektedirler. Aşık Mehmed'in (Ak, 1997, s. 406) ifadesine göre kentin bağlarını, bahçelerini ve bostanlarını içeren bu alanları Bijişkyan (1998, s. 102) batıda İmaret surlarının dışında, güneye ve batıya doğru da Kabakmeydanı'na-İncirlik' ${ }^{24}$ uzanan geniş bir bölge içerisinde tanımlar.

Surlarla çevrili alan ve varoşlara yayılan kent, Bijışkyan'a (1998, s. 103-104) göre Aya Ğorğor, Aya Yorgi, Hıristos, Aya Kiryaki, Aya Vasil, Faroz, Sotka mahalleleri olmak üzere yedi adet mahalleden oluşur. Kentin ana kiliselerinin ismini taşıdığın belirttiği bu yedi mahalle dışında ayrıca kentin doğu ucunda Çömlekçi ve Aya Filippo mahallelerinin de varlığından bahseder. Şakir Şevket (2001, s. 59), Bijışkyan'ın (1998, s. 103-104) belirttiği yedi mahallenin varlığını, isimlerini farklı zikretmekle birlikte, doğrular ancak "7 kilise adını taşıyan yedi mahalle"nin Osmanlı fethinden önce olduğunu belirtir. Bu mahallelerden Ayasofya, Meryem Ana, Ayafilbo, Ayvasıl ve Eksotha olmak üzere beş tanesinin ismini verir ve 19. yy.da kentin cami ismi ile anılan 32 mahalleden oluştuğunu belirtir.

Kentin fiziki dokusuna dair üç seyyahında neredeyse ortak bir dil ile vurguladığı tek bir husus vardır ki bu da Trabzon'un çok eski devirlerde "muhteşem" ve "çok nüfuslu" bir kent olduğudur. Bijışkyan (1998, s. 113) ve Şakir Şevket (2001, s. 77), 17.yy. Sultan Ahmed döneminde kentte 18bin hane bulunduğundan, yazarların metinlerini kaleme aldıkları 19.yy.da ise bunun yarısı kadarının mevcut olduğundan, diğerlerinin yok olduğundan ve yerlerine yenilerinin yapıldığını belirttirmektedirler. Ancak seyyahlara göre kent bu yeni ve eski yapılar ile birlikte hala çok güzel görünmektedir. Trabzon'un genel fiziki görünümünü tamamlayan diğer unsurlar ise sur dışında yer alan varoşlar ve bu varoşlarda uzanan meydanlardır.

Batı varoşu; Bıjışkyan'a (1998, s. 83-84, 102-103) göre Türklerin ve Rumların yaşadığ bu bölgede Sotğa, Faroz ve Ayasofya mahalleleri vardır. Seyyah bu mahallelerden kaleden 3

${ }^{24}$ Osmanlı kayıtlarında "Süleymân Bey" ve "Kabakmeydanı Camii" olarak geçen, günümüzde ki İncirlik Camii ve çevresi bu isimle anılmaktadır. 
mil (yaklaşık 5760m.) Akçaabat sınırında ve deniz kıyısında güzel bir tepe olarak tanımladığı Ayasofya'yı detaylı bir şekilde anlatır. Ayasofya Mahallesi olarak anılan bölgede 19.yy. da Müslüman evlerinin bulunduğundan, tepe olarak tanımladığı alanın çevresinin harap olmuş ve yıkılmış surla çevrili olduğundan bahseder. Ancak burada sur olarak bahsettiği yapı, "Rumlarn önemli kilisesi Ayasofya Kilisesi" olarak tanımladığı bugünkü Ayasofya Camii'nin bulunduğu alanı çevreleyen duvar olmalıdır. Seyyah, duvarlarla çevrili tepenin orta kısmına taş kemerler yapılarak zemin tevsiye edildiğini ve böylece oluşturulan düz alana kilisenin inşa edildiğini belirtir.

Doğu varoşu ise, çarşıları, hanları, hamamları ve camileri ile geniş bir yer olup "şehir" olarak adlandırılmaktadır. Bijişkyan (1998, s. 103-104) bu bölgeyi oldukça detaylı tanımlar ve sınırlarını; surlarla çevrili alandan doğuda Çömlekçi Mahallesine güneyde ise Boztepe'ye kadar uzanan geniş bir alanda çizer. Türk ve gayrimüslim birçok nüfusun birlikte yaşadığı belirttiği bu varoşun, denize uzanan kısmındaki Kanita (Ganita) ile kemer şeklindeki bir kayadan dolayı Kemerkaya denilen ve içerisinde bulunan tuzlu bir çeşmeden dolayı Tuzluçeşme olarak anılan mahallelerde de Rumlar'ın oturduğunu söyler. Sahile doğru uzanan Çömlekçi Mahallesi'nde de Rum çömlekçilerin bulunduğunu ancak eskiden burada Ermenilerin de ikamet ettiğinden bahseder. Bijişkyan'ın ifadelerinden daha önce Rumların piskoposluk kilisesi olan Aya Filippo'nun (St. Philiph/Esentepe Kudrettin Camii) bulunduğu bölgenin ise kilisenin camiye dönüştürülmesi ile Türk mahallesi halini aldığ1 anlaşılmaktadır. Seyyah bu mahallenin yukarısında zamanında Eleusa ${ }^{25}$ olarak ismini verdiği bölgeye kadar uzanan Hacı Osman Sokağı'nın varlığından bahseder ve bu sokakta eski zamanlarda sıra sıra dükkanlar bulunduğunu ve yakınında bulunan bir tarlanın içerisinde bulunan "dört köşe bir harabe" nin de eski bir hamam olduğu söylendiğini aktarır. Günümüzde Hacı Osman ismi ile anılan bir sokak olamamakla birlikte, üstünde Panaya adlı kilisenin kalıntılarını barındıran kayalık bir tepe olarak tanımladığı Eleusa'ya yani bugün Ganita olarak bilinen bölgeye kadar uzanan cadde, seyyahın tanımı ile birlikte değerlendirildiğinde Bııışkyan'nın günümüzdeki Taksim Caddesi ve devamındaki Gazipaşa Caddesi'ni tanımladığı anlaşılır (Üstün Demirkaya, 2014, s. 98).

Güney varoşlarında ön plana çıkan yer Boztepe'dir. Seyyahların betimlemelerinden Boztepe'nin kent için hem fiziki hem de dini önemi bulunduğu anlaşılmaktadır. Doğu varoşundan güneye doğru, çıkmaya başlanıldığında karşılaşılan Boztepe'yi Bijişkyan (1998, s. 110); kentin güneyinde yüksek olduğu için güney rüzgarlarını kesen, yeşilliklere de ev sahipliği yapan bir tepe olarak tanımlar. Şakir Şevket'e (2001, s. 116-117) göre Boztepe Trabzon kurulduğu günden beri önemli bir yer olarak görülmektedir. Geçmişi antik çağa kadar uzanan Boztepe'nin o dönemlerde "güneşe tapan putperestlerin" toplandığı bir yer olduğunu, o dönemlerden beri de kutsal bir yer sayıldığını belirtir. Hatta sonraki dönemlerde de yağmur duası için Boztepe çıkıldığını söyler. Bijişkyan (1998, s. 105), Boztepe'yi kayıtlarda da geçtiği gibi26 aşağı ve yukarı/güney olarak ikiye ayırır. Seyyah Boztepe'nin aşağı kısmına dair; bu bölgede Tavanlı Camii'nin varlığında değinir ve

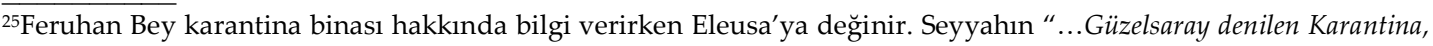
surlarla çevrili, üç katlı bir binadır. Limanın batı tarafında, Eleusa üzerinde bulunan bu meşhur bina, 1740 senesinde, Üçüncüoğlu Ahmet Paşa tarafindan yaptırılmıştır..." (Usta, 1999, s. 132) ifadesinden Üçüncüoğlu Ahmet Paşa tarafından inşa ettirilen, sonrasında karantina binası olarak kullanılan yapının bugünkü Ganita olarak anılan yerde olduğu bilinmektedir. Buradan çıkarımla Eleusa'nın günümüzde Ganita olarak anılan yer olduğu söylenebilir.

${ }_{26}$ İsmine ilk kez 17.yy.da da rastladığımız Boztepe Mahallesi'nin, 19. ve 20.yy.dan itibaren Boztepe-i Zir ve Boztepei Bala olmak üzere ikiye ayrıldığı görülmektedir (Üstün Demirkaya, 2014, s. 211).
}

SEFAD, 2020; (43): 435-466 
çevresinde Türklerin yaşadığı bilgisini verir. Bu bölgenin de aşağısına da ufak bir meydanı ve bu meydanın etrafında "Greklerden kalmış" olarak nitelendirdiği bir okulu ${ }^{27}$ ve camisi bulunan Zeytinlik Mahallesi ile Zeytinlik Mahallesinden geçilip ulaşılan Tekke Mahallesini konumlandırır.

Boztepe'nin güneyinde ise kente karadan gelenlerin kontrol edildiği nokta bulunduğunu ve buranın ismini Hoşoğlan ya da Ağaçbaşı mevkii olduğunu belirtir (Bijişkyan, 1998, s. 113). Bu bölgenin şehrin sınır noktası sayıldığı ve karadan kente gelen tüm yolcuların kontrol edildiği yer olduğu bilgisini verir. Ayrıca aynı yerdeki Hoşoğlan Çayı'na da atıfta bulunarak bu çayın ismine dair bir rivayeti aktarır; Fatih Sultan Mehmet'in fetih sonrasında burada idam ettirdiği bir gencin masum olduğunu anlayınca "Vah hoş oğlan" demesinin ardından çay bu isimle anılmıştır. Günümüzde Değirmendere sinırları içerisinde kalan bu mevkiinin yukarısına ise Meryem Ana Manastırını (Panagia Sümela/Sümela Manastırı) yerleştirir.

Seyyahlar tüm dönemlerde kutsallık atfedilen Boztepe'de birçok yapının varlığından bahsederler. Bijişkyan (1998, s. 108-109), kayalar içerisine oyulmuş Kırbatal Şapeli ve kente yaklaşık bir saat uzaklıktaki bir tepenin üzerinde, etrafında Ermeni mahallesi bulunan Amenapırgiç Manastırı'nın (Kaymaklı Manastırı) isimlerini sayarken, Şakir Şevket I. Aleksios Komnenos döneminde inşa edilen ve kullanılmamasına karşın gayrimüslimler tarafından senede bir kez ziyaret edilen küçük bir kilise ile bu kilisenin aşağısında Müslümanlara ait Ahi Evran Dede Türbesinden bahseder. Bijiskyan "Boztepe'de Ahremen Dede adlı mescit vardır." ifadesinde de muhtemelen yine Ahi Evren Dede'yi işaret eder.

Meydanların ilgili dönemlerdeki görünümleri oldukça detaylı aktarılmıştır. $\mathrm{Bu}$ meydanlar; doğuda Komnenos döneminde Maitanin, Osmanlı döneminde ise Gavur Meydanı, Kafir Meydanı gibi farklı isimlerle anılan ticari yolların kesişim noktası, batıda ise işlevine dair tartışmaların bulunduğu Kavak/Kabak Meydanıdır (Üstün Demirkaya, 2014, s. 345).

Gavur Meydanı'nı Bijışkyan (1998, s. 102); "278 kadem"28 (105m.) uzunluğunda, 180 adım (yaklaşık 136m.) genişliğinde, etrafında ev ve dükkanlar, doğusunda büyük bir cami ve çeşme, güneyinde meyve bahçeleri ve bir hizaya sıralanmış Ermeni evleri, yukarı tarafında ise Boztepe'nin eteğinde zamanında dervişlerin ikamet ettiği Tekke Mahallesi ile tasvir eder. Şakir Şevket'e (2001, s. 134) göre meydan yaklaşık 1850'lerde harap iken eserini de kaleme aldığı 1877'lerde birçok yapı ile donatılmıştır. Bu tarihte meydanda çok sayıda yapı, bahçe ve Islahhane'ye gelir olması amacıyla büyük bir gazino ve altında da sekiz adet mağazanın inşa edildiğini belirtir. Bijışkyan bu yapılara ek olarak, yine meydanın ortasında Hacı Abdullah Paşa tarafından inşa ettirilen dört eski mermer sütun üzerinde güzel bir şadırvanın varlığına değinir. Ancak Rus Harbi sırasında Rusların attıkları toplardan dolayı bu şadırvan ile birlikte meydanın da tahrip olduğunu açıklar.

Kabak Meydanl, hem Bijışkyan (1998, s. 85) hem de Şakir Şevket (2001, s. 109) tarafından at oyunlarının oynandığı alan olarak tanımlanır. Şakir Şevket bu iddiasına dayanak olarak İstanbul'daki Ok Meydanında bulunan nişan taşları gibi Trabzon'un Kavak Meydanı'nda da nişan taşlarının bulunduğundan bahseder. Bu nedenle meydanda

${ }_{27}$ Kiliseden dönüştürülen Zeytinlik Camii 1962 yılında yıkılmış, yine aynı isimle yerine inşa edilen yeni cami de, Zeytinlik Mektebi/Cudi Bey İlkokulu ile birlikte Tanjant yolu yapımı sırasında 2003 yılında yıkılmıştır. ${ }_{28} 1$ kadem 37,8869 cm.dir. Seyyah, Meydanın büyüklüğünü yaklaşık 105 m. olarak tanımlamıştır. 
muhtemelen ok atmak, silahşorluk ve at binme eylemlerinin gerçekleştirildiğini belirtir. Bijışkyan (1998, s. 85), meydanın aslında geniş bir alan olmasına karşın iki tarafından 1000 adımlık (yaklaşık $78 \mathrm{~m}$ ) alanın bahçe olarak kullanılmasından dolayı daraldığını söyler. Bijışkyan'a (1998, s. 85) göre meydanın asıl uzunluğu ise 400 adımdır (yaklaşık 314m). Eski zamanlarda hipodrom olarak da kullanıldığını belirttiği meydanda yer yer şapele benzeyen birkaç kubbeli sağlam eski yapıların varlığından bahseder. Ayrıca burada Türk Mahallesi bulunduğunu ve Süleyman Bey'in yaptırdığı "Kabakmeydan Camii" nin yer aldığını belirtir.

\section{Limanlar}

Trabzon'da kentin fiziksel mekanını belirleyici öğe, kenti savunmak amacıyla kurulan surlar iken; kent mekanının gelişiminde ve örgütlenmesinde (siyasi, askeri ve iktisadi açıdan) yönlendirici unsur ise; hemen her sur kapısında inşa edilen iskele ve etrafında örgütlenen ticaret merkezleri ile kentin dış dünya ilişkilerini kuran, deniz-kara ulaşımı ve bu yollar sayesinde ortaya çıkan ticari faaliyetlerdir (Aygün, 2005, s.136-137). Kent içinde ticaretin ağırlıklı olarak yürütüldügü merkezler ise ticaret yollarının kesişim noktası Gavur Meydanı ile birlikte surların hemen kuzeyinden doğuya doğru uzanan sahil bandı çevresinde yer alan çarşıdır.

Limanlar: Trabzon'da korunaklı bir yerleşim alanın sağlanmasının ardından, seçilen bölgede doğal limanın eksikliği; Aşağıhisar surlarının hemen önünde dalga kıranlarla korunaklı duruma getirilmiş, yapay bir liman, Moloz Limanı inşası ile giderilmiş, 1. yy.da inşa edilen Hadrianus'un limanı kentin tarihi boyunca dış dünyaya açıldığı kapısı olmuştur. Bijıskyan'da (1998, s. 90, 100) bu bilgiyi doğrular ve "meşhur" Trabzon Kalesinin eski zamanlardaki alametinin gemi demiri olduğunu hatta eski Trabzon sikkelerinin bir yüzünde Apollon başı, diğerinde ise gemi burnu ve çapa olduğundan, bunun nedeninin de kagir liman binasının yapılışından sonra birçok geminin buraya yanaşması olduğu belirtir. Moloz Limanı olarak bilinen bu liman Şakir Şevket'in (2001, s. 122) aktardığına göre 3.yy'da inşa edilmiştir. Ancak Bijışkyan (1998, s. 101-102) bilinenin aksine bu limanın Ksenofon'dan çok önce "büyük gayret ve masrafla" yapıldığından, Hadrianus'un muhtemelen tamir ettirdiğine değinir. Seyyah, kendinden önceki yazarların da "muazzam" olarak tasvir ettikleri limanın denize atılan temeller ile kalenin 3 katı haline getirildiğini ancak metnini kalem aldığ dönemde yalnızca duvar kalıntılarının varlığından ve bunların denizin içinde üç taraftan görülebildiğinden bahseder. Doğuya doğru açllan liman ağzının büyük gemilerin geçebileceği uygun genişlikte ve uzunluğunu 1 mil (yaklaşı $1.9 \mathrm{~km}$ ) olarak tanımlar ve bu hali ile elliden fazla gemiyi barındırabildiğinden bahseder. Limanın batı tarafında ve su seviyesinde bulunan bir adacığın üzerinde ise gemileri ikaz etmek amacıyla işaretler görüldüğüne değinir. Trabzon'un büyük limanının ise Çömlekçi Limanı olduğunu belirtirken buranın geniş ve açık bir yer olmasına karşın sığ olmasından kaynaklı yalnızca yaz aylarında kullanılan "yazlık" bir liman olduğundan bahseder. Kent surlarının kuzeyinden Çömlekçi Limanı'na kadar yer yer kayalıklar bulunduğundan ve bu limana kadar Moloz, Kanida, Tuzluçeşme, Taşdirek, Kemerkaya, Mumhaneönü isimli küçük ancak her türlü ihracat ve ithalatla birlikte oldukça aktif olduğunu belirttiği limanların varlığına değinir (Bijışkyan, 1998, s. 110, 112).

Şakir Şevket (2001, s. 48) ise "yuvarlak taş" olarak tanımladığı muhtemelen kayalıkların Faroz Mahallesinin önünde bulunduğundan bu nedenle gece vaktinde veya fırtınalı havalarda pek çok kayığın hasar aldığını anlatır. Atlatılan büyük bir kaza sonrasında kayıkların taşlara çarpmaması amacıyla ağaçtan direk dikildiğinden, kendi zamanında ise 
bu direğin yerini taş direk aldığını belirtir. Şakir Şevket'in (2001, s. 48) tanımı, Bıjışkyan'ın (1998, s. 112) ismini saydığı limanlardan Taşdirek Limanı'nı akla getirir. Her iki seyyahında birbiri ile yakın dönemli oldukları düşünüldüğünde, yerine dair herhangi bir bilgi bulunmayan Taşdirek Limanı ile Faroz Mahallesi önündeki kayalıklı alanın aynı yeri işlevi gördüğü düşünülebilir.

Şakir Şevket (2001, s. 56-57), Trabzon limanlarının fiziki durumlarına ve inşalarına dair önemli bilgiler verir. Moloz Limanı'nın kumluk olduğundan dolayı fırtınalı zamanlarda gemilerin karaya oturduğundan bahseder. İstanbul'dan Trabzon'a deniz yolculuğuyla gelinirken Trabzon limanından önce iki limanın varlığından ve bu limanlardan Trabzon'a en yakın olanının 2-3 saatlik mesafede yer alan Pulathane Limanı'nın, muhtemelen firtınalı havaları kastederek ve alternatif liman olarak, yolcu ve yük indirmek için daha uygun bir konumda olduğunu belirtir. Avrupa'dan gelen ticaret malları Erzurum üzerinden İran'a kadar sevki Trabzon Limanı üzerinden gerçekleştiğinden, Trabzon'da iki liman yaptırılması düşünüldügünü ve mühendislerin Trabzon'da gerçekleştirdiği incelemeler neticesinde, 20bin kese akçe bedel ile inşa edilen, "Kalafataltı Mahallesi" olarak isimlendirdiği bugünkü Çömlekçi Limanı'nı anlatır. "Kalafataltı İskelesi" olarak da bilinen yapıyla birlikte ambar, gümrük binası odaları ve rıhtım inşa edilmiş olmasına karşın limanın kuzey batıdan esen sert rüzgârlara açık olması nedeniyle Pulathane Limanı'na olan ihtiyaç devam etmiştir (Yilmaz, 2015, s. 223).

Bijışkyan (1998, s. 106), Trabzon Çarşısı'nda eskiden İran ile ticaret yapan Ermeni tüccarların bulunurken, 19.yy.da artık Türk tüccarlarında yer aldığını belirtir. Seyyah, çarşı içerisinde yalnızca Çarşı Camii ve bu cami etrafındaki yapılardan Taşhan ile Bedesten'e değinir. Çarşının merkezinde, Çarşı Camii'nin karşısında yer alan Bedesten'i; dört köşe yüksek bir yapı olarak tanımlar. İçeriye açılan, dört yönden, karşılıklı gelecek şekilde dört kapisının ve buradan uzanan yolların odak noktasında da su kuyusu bulunduğundan bahseder. Bu kapılardan doğu kapısı üzerindeki kitabe levhası için; burada yer alan bozuk yazıların Cenovalılara ait olduğunun söylendiğini ancak bunu soruşturmasının mümkün olmadığını belirtir. Seyyah yapı ile ilgili yaptığı gözlemde; "yap yüksektir ve önce dört sütuna oturtulmuş, ikinci bir katı da varmış fakat yangından sonra dükkanlar tek katlı olarak yapılmıştır" demektedir (Bijışkyan, 1998, s. 105-106). Bedestenin 2000 yılında geçirdiği restorasyona kadar ki çatısı yıkık durumunu daha geç dönemde, muhtemelen Bijişkyan'ın belirttiği gibi yangın veya benzeri bir felaketle aldığı anlaşılmaktadır. Seyyahın çarşı içerisinde bahsettiği bir diğer ticari yapı da, Çarşı Camii'nin güneydoğusunda yer alan, seyyahın önemli yapılar arasında saydığı Taşhan'dır. Taşhan'ın günümüzdekinden farklı bir görünümde olmadığı "eski, kemerli ve iki katlı" tanımından ile anlaşılmaktadır. Bu yapılar dışında deniz üzerinde iki katlı, taş merdivenli yüksek bir yapı olarak tanımladığı Gümrük binası ve yanında tıpkı Taşhan gibi iki katlı bir han ile birlikte Müftü Hanı ve hamamı, Yalı Hanı, Paşa Hamamı, Tabakhane Camii gibi başka "büyük yapılar" olarak nitelendirdiği yapıların yalnızca isimleri zikreder (Bijşkyan, 1998, s. 106).

\section{Dini Yapılar, Bayındırlık Yapıları, Köprüler, Hamamlar}

Trabzon kenti tarihi boyunca koruduğu ticari önemiyle de birlikte, her dönemin ve toplumun herkesin imzasının olduğu renkli bir ortam sunar. Trabzon'u konu alan, Trabzonlu seyyahların seyahatnamelerinde; metinlerini kaleme aldıkları dönemde var olan, kalıntıları duran veya o döneme ulaşmamış olsa dahi varlığından haberdar oldukları çok 
sayıda kilise, cami gibi dini yapılar ve bunların çevrelerinde yer alan birçok yapının varlığı dikkati çekmektedir.

\section{Kiliseler}

Dini yapılar üzerinde seyahatnamelerde özellikle durulmasına ve bu yapılar hakkında pek çok bilgi verilmesine karşın, Trabzon'da yer alan kiliselerin özellikle Bijişkyan'nın ilgisini çektiği görülmektedir. Muhtemelen Vikerlik görevinin etkisiyle o dönemde ayakta olan, kalıntıları bulunan veya gezisi sırasında görmese de haberdar olduğu çok sayıda kilisenin varlığından, isimlerinden bahseder. Ayrıca kentte kilise inşasına dair, eski zamanlarda Trabzon'un ileri gelenlerinin yılın her günü için birer kilise yaptırdığından, Trabzon'da 365 tane kilisenin bulunduğunun söylendiğini, ancak bu 365 kiliseden, 7 tanesi önemli olmak üzere sadece ancak 24 tane kilise kaldığını belirtir. Bunların yanında bazı manastırlar, misafirhaneler ve birçok evde de hususi şapeller yer aldığını söyler (Bıjışkyan, 1998, s. 103).

Grek Kilisesi: Bijıskyan (1998, s. 96-97), Ortahisar'ın kapılarından olan Debbağhane (Tabakhane) Kapısı'nın, iç kapı olarak isimlendirdiği kapısının yanında bulunan yüksek bir kemerin üzerinde zamanında denize ve karaya nazır bir kilisenin varlığından bahseder ve yapıyı Grek Kilisesi olarak isimlendirir. Taş bir merdivenle çıkılan kilisenin mihrabının doğu tarafta hala görülmekte olduğunu ve altında da bir avlunun yer aldığını iletmektedir. Kilisenin kendi zamanında (19.yy.ın ilk yarısında) hücrelere ayrılarak ulemanın oturduğu ve mahkemelerin görüldüğü yer olarak dönüştürüldüğünü ifade eder.

St. Evgenios Kilisesi (Yeni Cuma Camii): Yapı, Boztepe'nin batı ucunda yer almaktadır. Aşık Mehmed (Ak, 1997, s. 407), Fatih Sultan Mehmet'in şehri fethettikten sonra ilk Cuma namazını burada kılmasından dolayı kiliseye "Yeni Cumağa Camii", mahalleye de "Yenicumağa Mahallesi" isimleri verildiğini belirtir. Nitekim, günümüzde de hem yapı hem mahalle aynı isimle anılmaya devam etmektedir. Bijışkyan'ın (1998, s. 102) ifadesine göre İmparator Aleksios'un Evgenios adına yaptırdığı söylenilen kilise, yüksek kubbeli büyük bir yapıdır. Ayrıca kilisenin kalıntılarından manastır ve şehitlik bölümlerinin izleri ve kapı kısımlarının, yeni yapılan evlerle kapanmış olmasına rağmen görülebildiği ifade eder. Aşık Mehmed (Ak, 1997, s. 407), uzun ve geniş olan camiye Cuma namazı kılınabilmesi için fetihten sonra minber, müezzin mahfili eklendiğini aktarır.

St. George Rum Kilisesi: Yalnızca Bijışkyan'ın (1998, s. 102) bahsettiği Hıdrellez de denilen küçük yapı kendi ifadesine göre, Kuzgundere üzerinde ve St. Evgenios Kilisesi'ne (Yeni Cuma Camii) buraya yakın bir konumdadır.

Altınbaş Kilisesi (Panagia Chrysokephalos): Günümüzde, Ortahisar Fatih Camii olarak bilinen kilisenin kitabesine ulaşılamasa da, Bijışkyan (1998, s. 94-95) Justinianos zamanında yapıldığını ve Aleksios Komnenos tarafından tamir edildiğini tahmin ederek aktarır. Şakir Şevket, Apostolus Andriyasi ismindeki bir şahsın, Tuzluçeşmede ${ }^{29}$ ikamet ederken Trabzon halkını Hristiyanlığa davet etmesiyle dönemin Trabzon Kralı Andivalyanos'un tarafından Meryem Ana isminde kilise yaptırdığını, Komnenosların buraya gelmesinin ardında ise bu kiliseye Altunbaş Kilisesi adının verildiğini aktarır. Son olarak üç seyyahında aktardığı üzere yapı, Osmanlı fethinin ardından camiye dönüştürülmüştür. Aşık Mehmed (Ak, 1997, s. 406), Fatih Sultan Mehmet'in, fethin ardından bu caminin doğu duvarına bitişik ahşap kaplamalı ve ahşaptan yapılmış yüksek bir mekanda (makam-ı fevkani) Cuma namazını

${ }_{29}$ Günümüzde İskender Paşa Mahallesi'nin kuzeyinde ve Kemerkaya Mahallesi'ne sınır alan olarak tarif edilebilir. SEFAD, 2020; (43): 435-466 
kıldığını ifade eder. Aşık Mehmed (Ak, 1997, s. 406) ve Şakir Şevket (2001, s. 73) benzer ifadeler ile yapının camiye çevrilmesinin ardından kilisenin tamir edildiğini, bu tamirler sırasında yeni hücreler ve bir medresenin de kiliseye ilave edildiğini belirtirler. Bijıskyan (1998, s. 94-95) kalenin orta kısmında (Ortahisar) yer almasına atıfta bulunarak Ortahisar Camii olarak andığı yapıya dair oldukça detaylı bilgiler verir. Baş mihrabın yerinin geniş ve aydınlık, duvar ve zeminin mermerlerle döşeli olduğunu, kral tahtının güney tarafta kemerli camekanın yanında yer aldığı tanımının ardından yapıyı üç kısımda tanımlar. Birinci kısım, cam kısım ve tahtla beraber mihrabın bulunduğu bölümdür. Bu kısmın doğu tarafında pencereler, kuzey tarafında da ikinci kata çıkan taş basamaklı taş bir merdiven vardır. İkinci kısım ise cam mekandan başlayan ve büyük kubbenin altında düşen geniş bölümdür. Kilisenin büyük kapısının da bu kısmın kuzey tarafında olduğunu ve kapının dışında güzel avlu açıldığını belirtir. Kilisenin bu kuzey kısmında putpereslik tapınağından kaldığı zannedilen iki muazzam mermer sütununun varlığından bahseder. Kilisenin üçüncü kısmı batı tarafında olup üstünde, kadınlara mahsus taş zeminli galeri bulunduğundan, bu galeriden üçüncü kata gidildiğinden bahseder. Kapılarla ayrılmış olan iki kat, kraliyete mensup kadınlara, asıl galerinin ise halka ayrıldı̆̆ını tahmin etmektedir. Batı kapısının bulunduğu bu üçüncü bölümden, yerden 150 adım (117m.) uzunlukta ve 50 adımdan (39m.) fazla genişlikte olan kilisenin büyüklüğünün göründügünü söyler. Bijışkyan, yapının bezemelerine dair başmihrabın arka kısmındaki yüksek duvarın solunda "müjdeleme"yi temsil eden bir mozaiğin olduğundan ve sağ tarafta da başka bir mozaiğin izleri olduğundan bahseder. Bijıskyan döneminde bu mozaiklerin izleri görülse bile 2018 yılında gerçekleştirilen restorasyon çalışmalarında duvarlardaki mozaiklere rastlanmamış fakat zeminde $100 \mathrm{~m}^{2}$ den fazla bir alanda mozaik süslemeler ortaya çıkartılmıştır.

Bijışkyan (1998, s. 95) muhtemelen metni kaleme aldığı yıllardan bahsederek yapının bulunduğu alanı; dükkan, medrese, şadırvan, çeşme ve eskiden kalmış bir kuyu ile tanımlanan, zemini taştan bir "meydan" olarak belirtir. Meydanın doğusunda bir çeşme olduğundan ve bu çeşmenin üzerinden üzerinde İmparator Aleksios'un koyduğu bakır ejderin olduğu rivayetini dile getirir. Şakir Şevket (2001, s. 52-53) ejderha ağzı figürünün oluk olarak yaptırıldığını, Osmanlı döneminde ise bu çeşmeden alınarak başka bir çeşmeye takıldığını ifade eder. Bijişkyan (1998, s. 95) alanı tanımlamaya devam eder ve meydanın kuzey tarafında bir kuyunun yer aldığını, bu kuyunun önünde ise eski binalardan kalmış İon sütun başlığından yapılmış yekpare bir kurnanın yer aldığı ifade edildiğini aktarır. Kendisinin de meydanın doğu tarafındaki, sütunların üzerinde, cephesinde haç işaretleri bulunan eski bir bina gördüğünü, bu binanın bir kısmının yeni bir binanın içinde kaldığından bahseder. Binanın meydanda kalmış olan batı kısmında son zamanlarda şehit mezarlarının bulunduğunu ifade ederken, buranın şehit mezarlığı olması gerektiğini söyler. $\mathrm{Bu}$ varsayımını desteklemek için mabedin doğu tarafında Zağnos Kapısı'nın yanında kemerli şapelin içinde lahit bulunduğunu söylemektedir. Uspenski'de (2003, s. 96) 20.yy başlarında, yaptığı kazı çalışmaları sonucunda yapıdan IV Aleksios'a ait lahit bulunduğunu belirtir. Ancak Trabzon'a ait eldeki en erken tarihli harita olan 1926 yılina ait harita da yapının yer almaması, mabedin 1429'de Alexios'un ölümünden sonra yapıldığını ve 1926 yılından önce yıkılmış olduğunu düşündürür (Belge, 2018, s. 251).

Aya Vasili Kilisesi: Kaynaklarda St. Basil Kilisesi (Lowry, 2005, s. 141) olarak geçen yapının ismine üç seyyahtan yalnızca Bijişkyan'ın eserinde rastlanmaktadır. Bıjişkyan'ın (1998, s. 104) "1339 sene önce Imparator Justinianos tarafindan yaptırlmıı̧tır" ifadesinden yapının 6.yy.da inşa edildiği anlaşılır. Günümüzde ayakta olmayan yapı, seyyahın ifadesine 
göre 9 arşın (yaklaşık 6.82m.) yüksekliğinde ve dokuz karış (yaklaşık 1.8m.) kalınlığında dört mermer sütunun üzerinde yüksek bir kilisedir. Ayrıca seyyah Aya Vasili Kilisesi'nin günümüzdeki Kahramanmaraş Caddesi üzerinde yer alan St. Anne (Küçük Ayvasıl) Kilisesi ile yakın konumda olduğunu belirtir.

St. Anne Kilisesi: Günümüzdeki Kahramanmaraş Caddesi üzerinde, deniz ile kalenin karşısında yüksek bir konumda bulunan St. Anna Kilisesi de eski bir yapıdır. Küçük Ayvasıl Kilisesi ismiyle de bilinen yapıya dair bilgi veren Bijişkyan (1998, s. 104), kapısı üzerinde yer alan bozulmuş kabartmalı bir taşta kanatlı kadın ve çeşitli şekiller görüldüğünü söyler. Bıjışkyan (1998, s. 104), taşın putperestlik zamanında yapılan bir yapıdan buraya getirildiğini veya yapının eskiden put tapınağı olup daha sonradan kiliseye çevrildiği yönünde varsayımlar yapar.

Kızlar Manastırı: Theotokos Theoskepastos (Kızlar/Rahibeler) Manastırı kentin güney ucunda Boztepe'nin eteğindedir. Bijıskyan'ın (1998, s. 104-105) doğal bir sur etkisi yaratan Boztepe'nin de etkisi ile ufak bir kale görünümünde olduğunu, konumundan dolayı kentin her noktasından görülebildiğini belirttiği yapı bugünde bu özelliklerini korumaktadır. Seyyah yapının fiziksel özelliklerine dair; Rum rahibelerin ikamet ettiği manastır kilisesi ve avlusunun kayaya oyulduğu, kale suru gibi metin duvarlarının içine oyularak yapılmış hücrelerin yer aldığı oyulduğu ve kuzey tarafında İmparator Aleksios'un yüksek ve duvarla çevrili taht yeri bulunduğu bilgilerini verir.

Kırbatal Şapeli: Bu yapının ismine Bijıssyan'dan başka kaynakta rastlanmamıştır. Seyyah yapının Boztepe'nin doğu ucunda, günümüzde Ganita/Kalepark olarak anılan bölge olduğu anlaşılan, Eleusa'nın (Ganita) karşısında, kayalar içerisine oyulmuş bir kilise olarak tanımlar. Seyyah ayrıca, bir rivayete dayanarak Boztepe'de kayaların içine oyulmuş Kırbatal'a inen garip bir yolun varlığından ancak şapelin içerinde ikonlar ve ayazma olmasına rağmen buraya çok zor ulaşıldığından bahseder (Bijışkyan, 1998, s. 110-111).

St. Sava Kilisesi: Bijışkyan (1998, s. 111) Boztepe'de Kırbatal Şapeli'nin aşağısında, yine kayanın içerisine oyulmuş ikinci bir şapel olan St. Sava Kilisesi'nden bahseder. Kentte bulunan mağara kiliselerinden biri olan ve St. Sabbas Manastırı/Maşatlık Kilisesi/Mağara Kilisesi gibi isimlerle anılan yapı günümüzde Esentepe Mahallesi'nin Boztepe yamaçlarında yer almaktadır. Bu yapı kompleksi doğu, batı ve kuzey olmak üzere üç ana grupta toplanan dört mağara kilisesinden oluşur ve tamamen kayaya oyularak inşa edilmiştir (Horuluoğlu, 1978, s. 35-36).

Surp Oksent Kilisesi: Kiliseye, Türkler tarafından Sulumanastır denildiğini belirten Bijışkyan (1998, s. 107), yapının kü̧̈ük olmasına karşın üç mihrabının bulunduğunu ve çok fazla ilgi gören Meryem Ana tasvirine sahip olduğunu belirtir. Feruhan Bey'in ${ }^{30}$ "Meydan'a yakın olan ve yanında bir mezarlh̆̆ı bulunan Surp Oksent Kilisesi ayn zamanda Ermeni murahhaslık makamıdır." şeklindeki ifadesi günümüzde bulunmayan yapının yerini tanımlar (Bijıskyan, 1998, s. 137).

Amenapırgiç Manastırı: Günümüzde ise Kaymaklı Manastırı olarak anılan yapı, güney varoşlarında, Boztepe'nin Değirmendere Vadisi'ne bakan yönünde bulunmaktadır. Bijişkyan

\footnotetext{
301847 yılında Sultan Abdülmecid tarafından Bağdat'a kadar bir inceleme gezisine gönderilen Ragıb Bey'e refakat eden Doktor Perunak Feruhan Bey, yol boyunca uğradıkları yerler hakkında bir seyahatname kaleme almıştır. Metin çalışmaya doğruca konu olmasa da Bijişkyan gibi kiliseler hakkında verdiği bilgiler nedeniyle önemlidir.
} 
(1998, s. 108), manastır kilisesinin narteks ve üç şapelden oluştuğunu belirtir ve bu kiliseleri; batı tarafta dört köşe olan güzel yapı Asduadzadzin, doğu tarafında bahçesiyle birlikte Surp Ohannes, üçüncü şapel ise yerini belirtmeden Surp Yerortutyun olarak siralar. Surp Yerortutyun Kilisesi'nin batı tarafındaki çan kulesinin üzerinde yer alan kitabeye göre kilisenin Koca Bağdasar, altta yer alan hücresinin de keşiş Asduadzadur tarafından tamir edildiğini yazar.

Surla çevrili hücreleri ve galerisi ile kentin doğu tarafında ve kentten yaklaşık bir saat uzaklıktaki bir tepenin üzerinde sağlam şekilde duran Amenapırgiç Manastırı'nın ise kilisesinin kapısı üzerinde yer aldığını söylediği kitabesine dayanarak, İmparator Aleksios zamanında 1424 senesinde doğudan gelen Şemsedli lakaplı Koca Stepanos tarafından yapıldığını belirtir. Manastırın aşağısında ve kent tarafında yer alan kilisenin adıyla Aya Mam ya da Aziz Manas adıyla anılan bir Ermeni mahallesi bulunduğundan, kalıntıları bir tepenin üzerinde yer alan kilisenin altından manastır kilisesinin mihrabının altına kadar uzanan bir yeraltı geçidinin varlı̆̆ından söz edildiğinden bahseder. Manastır alanının da bir zamanlar kentin ucunda bulunan Aya Filippos'a (bugünkü Esentepe Mahallesi) kadar uzanmış olduğu fermanlarda belirtildiğini söyler (Bijişkyan, 1998, 108-109).

Surp Ohannes Kilisesi: Bijişkyan'nın (1998, s. 108), Kaymaklı Manastırı (Amenapırgiç)'nın doğusunda yer aldığını belirttiği kilise, seyyaha göre manastırla bağlantılı üç şapelden biridir. Dar mezarlığı, avlusu ve yıkık çan kulesiyle birlikte çarşıya yakın bir konumda küçük bir mabet olarak tanımlar. Kapı üzerinde yer alan süslemeler arasında Ermenice yazılar mevcut olduğunu söyler ancak herhangi bir açıklama yapmaz. Bu yapının da yerine dair ipucunu yine Feruhan Bey'de bulmak mümkündür. Seyyah yapının Berberoğlu denilen yerde bulunduğunu belirtirken ismini muhtemelen okuma/telaffuz farkından Surp Hovannes olarak verir. Bıjişkyan, yapıyı Ermeni kiliseleri içerisinde saymasına karşın, avlu içerisinde Ermeni ve Rum evleri bulunduğundan, yapının eskiden Rumlara ait olduğuna dair bir rivayetin varlı̆̆ından da bahseder.

Asduadzadzin Kilisesi: Bijıskyan (1998, s. 106), beş mihrap, çan kulesi ve kalın bir duvarla çevrili avludan oluşan yapının, Trabzon'da Aleksios zamanında yaptırılan dört tane Ermeni kilisesinden biri olduğunu belirtmektedir. Surp Ohannes Kilisesi ile ayrıntı vermeden yalnızca ismini zikrettiği Surp Yerortutyun ile birlikte Kaymaklı Manastırı (Amenapırgiç) ile bağlantılı üç şapelin içerisindedir. Narteks'inde yer alan Surp Hagop isimli mihrabının üzerindeki kitabeye göre yapının Ağripşin tarafından 1414 yılında yapıldığını söyler. Seyyah yapının mimarisine dair de bilgiler verir: Kalın duvarlar üzerine oturtulduğunu tahmin ettiği kubbesinin kenti fethi sırasında yıkıldığını ve muhtemelen Yavuz Sultan Selim zamanında kalın merteklerle desteklendiğini, çan kulesi, narteks kubbeleri üzerinde oturtulmuş olduğunu ve bu kulenin arkasında Koca Stepan'ın soyundan gelen Haçeres ve Melik Ohannes isimleri ile 1429 yılında yaptırıldığına dair başka bir kitabe bulunduğunu belirtir. Kilisenin kuzeyde ve güneyde olmak üzere iki kapısı mevcut olduğundan ve bu kapılardan kuzeydekinin yanında yüz yıllık bir yazı ile bir şehit mezarı yer aldığını söyler. Karşısında kilise evi ve 1818 yılında kendi ailesinin (Bıjışkyan'ların) yaptırdığı mektep bulunan cümle kapısı ya da ana giriş kapısı yolun üzerinde olduğunu, güney kapısının ise kadınlara mahsus olup galeriye açıldığını belirtir (Bıjişkyan, 1998, s. 107).

Çarhapan Kilisesi: Bijışkyan (1998, s. 107), ismini saydığı ikinci Ermeni kilisesi olan yapı hakkında, Hz. İsa'nın namına yaptırtılmış ama yapıldığı tarihte tepeden aşağıya düşen bir 
adamın sapasağlam kalması sebebiyle Çarhapan yani "fenalı̆̆ı engelleyen" adının uygun görüldüğünü söyler. Üç mihrap ve yüksek bir çan kulesinden oluşan kilisenin, kitabesine göre, Amenapırgiç (Kaymaklı) Manastırı'nın da banisi olarak zikrettiği, Koca Şemsedli tarafından 1431 tarihinde yaptırıldığını belirtir. Seyyah, asıl kilise kısmının narteksten ve kadınlar kısmından kalın bir duvarla ayrıldığını bu nedenle sağlam bir yapı olduğundan bahseder. Kilisenin avlusunda üzerinde haç şekilleri ve bir azizin tasvirinin yer aldığını fakat tahrip olan bu şekiller hakkında hiçbir yazının bulunmadığını söyler. Bijışkyan, kilise yapılmadan öncede burada ayinlerin yapıldığını bu nedenle de buradaki şapelin inşa tarihinin daha eskilere dayanması gerektiğini düşünür. Kilisenin önünde geniş bir mezarlık olmasına rağmen İskender Paşa'nın açtırdığı yol sonrasında mezarlığın bir kısmı yola gittiğini belirtir. Kentte Ermeni mahallerinin konumu dikkate alındığında, yapının doğu varoşlarında bulunduğu (Üstün Demirkaya, 2014, s. 106), mezarlık alanının ise günümüzde ki Fatih Parkı'nın yerinde, Taksim ve Erzurum Caddeleri arasında uzanan Taksim Mezarlığı'nın (Belge, 2018, s.165-166) bir parçası olduğu söylenebilir.

St. Philiph Kilisesi: Yapı, fethin ardından Panagia Crysokephalos Kilisesi'nin camiye çevrilmesi ile Bijişkyan'ın (1998, s. 109) da bahsettiği gibi kentin katedral kilisesi olmuş, 1665 yılında ise Kudrettin Camii ismi ile camiye çevrilmiştir (Kurnaz, 1994, s.95). Fetih sonrasında da kent için önemli yapılardan biri olmasına karşın yapının ismine yalnızca Bıjişkyan'nın metninde rastlanır. Mimarisi hakkında daha fazla bilgi vermemekle birlikte caminin yanındaki çeşmeden bahseder. Çeşmenin dönemin piskoposun kızı tarafından yaptırıldığını, denetiminin ise fermanla birlikte eskiden orada oturan Ermenilere bırakıldığından bahseder.

Ayasofya Kilisesi: Kentin batısında, günümüzde Fatih Mahallesi sınırlarında bulunan yapıyı Bijiskyan (1998, s. 83); "Ayasofya, üç mil ötede deniz kıyısında güzel bir tepedir. Etrafinda Müslüman evleri vardır ve Ayasofya Mahallesi adını taşır. Tepe bugün birçok yerleri yıkılmış bir surla çevrilidir. Tepenin orta kısmının etrafina taş kemerler yapılmış ve zemin tesviye edilerek düzlük haline getirilmiştir. Rumların muhteşem Ayasofya Kilisesi bu düzlüğün üzerinde yapılmıştır." şeklinde tanımlar. Diğer bahsi geçen kiliselerin aksine Ayasofya Kilisesi'ne her üç seyyahta değinir. Şakir Şevket (2001, s. 53), kilisenin 1245 tarihinde inşa ettirildiğini, İstanbul'daki Ayasofya'dan daha kıymetli ve daha eski olduğu rivayetinin gerçeği yansıtmadığına vurgu yapar. Ancak Bijiskyan (1998, s. 83) kilisenin Şakir Şevket'in (2001, s. 53) verdiği tarihe denk gelen Aleksios Komnenos döneminde tamir ettirildiğini, inşasının ise "ilahi hikmet'e ithafen" İmparator Justinianos tarafından yapıldığı bilgisini verir.

Yapının mimarisine dair detaylı bilgiyi yine Bijiskyan(1998, s. 83-85) verir. Herhangi bir özen gösterilmemesine karşın, bir taş bile yerinden düşmeden sağlam kaldığını belirttiği kiliseye dair; İon başlıklı, dört köşeli yapının üç tarafında ikişer mermer üzerine oturtulmuş kemerli avlular yer aldığı, batı tarafında yer alan avlunun en büyük olduğu ve büyük kapının da bu avluya açıldığı, güney kapısının cephesinde melek, insan, haç ve aslan başları en üstte de imparatorluk kartalı kabartmaları işlendiği bilgilerini verir. Mihrabın geniş ve yüksek kubbesinin de her birinin uzunluğu 12 arşından (8m.) fazla olan, yer yer renkli beyaz mermerden tek düze şeklinde inşa edilmiş 4 adet "muhteşem" sütun üzerine oturtulduğunu söyler. Kilisenin zemini mermer taşlarla döşeli olsa da orta kısmın bozulduğunu, fetihten sonra camiye dönüştürüldüğü için güney tarafında namaz yeri bulunduğunu belirtir. Tasvirlerle süslenmiş dört köşe bir şapel olarak tanımladığı yapının içinin dört köşe sütun ve kapıları olan dört kısma ayrıldığından bahseder. Ayasofya Kilisesi'nin güneyinde, tepenin ucunda bulunduğunu belirttiği dört köşe kagir bir yapının da bekçi ve hademelere hizmet 
ettiğini söyler. Batı taraftaki çan kulesini ise; dört köşeli, iki kattan oluşan merdivenden birinci kata çıkıldığında, ayin masası ile 3 adım $(2.5 \mathrm{~m})$ genişlikte ve resimlerle süslü bir küçük şapelin içine girilir şeklinde tanımlar. Çan kulesinin avlusunun yakınlarında gördügünü söylediği yıkıntılarında "Thukykos'un o zamanki meşhur okulu" olarak rivayet edildiğini belirtir. Aşık Mehmed (Ak, 1997, s. 407) ve Şakir Şevket (2001, s. 60, 123) ise özellikle kilisenin Osmanlı fethi sonrası durumundan bahseder. Aşık Mehmed (Ak, 1997, s. 407) kilisenin H.980 (1572/73) yılında camiye çevrilerek Cami-i Ayasofya ismini aldığını, Cuma namazı kılınabilmesi için de yapıya minber ve müezzin mahfili eklendiğini belirtir. Bunun dışında Cami-i Ayasofya'nın uzunca bir yapı olduğu, içerisinde mermer sütunların yer aldığı ve çevresinde zeytin ağaçlarının olduğu aktarırlar.

Aya Gorgon: Bijiskyan (1998, s. 103), Rum piskoposunun makamı olarak tanımladığı kilisenin, Tuzluçeşme Mahallesi'nde, deniz kıyısındaki kayanın üzerinde inşa edildiğini belirtir. Ayrıca Son Gürcü kralının mezarı ve başlıca Rum mekteplerinin de burada bulunduğunu söyler. Seyyahın tanımları bahsi geçen yapının; yakın zamana kadar ayakta olan ancak çeşitli kent içi çalışmalarından dolayı yıkılmış olan şimdiki Kemerkaya Mahallesi içerisinde St. Gregory of Nyssa Manastırı ile aynı yapı olduğunu düşündürmektedir.

\section{Mescit ve Camiler}

Boyahane Mescidi: Bıjıskyan (1998, s. 98), Aşağıhisar surlarının batı kapısının yakınında kemerli ve çift katlı eski bir yapı olduğunu söyler. Yapıda Grekler zamanında değişikliklerin yapıldığını ve yapıya dair net bilgileri de dış duvarlarında yer alan birçoğu bozulmuş Grekçe yazılar sayesinde edindiğini buna göre de mescidin imparatorluğuna ait kendi zamanına göre yapının 513 yıllık (yaklaşık 13.yy) olduğunu belirtir. Yapıyı eski bir manastıra benzetir. Hatta putperestlik devrinde kahinlerin ikamet ettiği yer olduğunu belirtir. Mescidi; alt kısmı kemerli ve iki taraftan mermer sütunlar üstüne oturtulmuş, aslında yüksek bir yapı olmasına karşın zeminin sütun başlıklarına kadar doldurulması nedeniyle yer seviyesinde bir yapı olarak tanımlar. Yapının yakınında, kuzeye doğru bir harabenin ve mescit avlusu denilen bir meydanın yer aldığını aktarır.

Çarşı Camii: Günümüzde de aynı isim ile anılan yapı, Çarşı Mahallesi'nde yer almakta ve kuzey cephesindeki giriş kapısı üzerindeki kitabesine göre 1839 yılında Hazinedarzade Osman Paşa tarafından yaptırılmıştır. Bijışkyan (1998, s. 103) Çarşı Camii'ni; çarşı içinde, yanında dört köşe bir bina yer alan eski bir kilise olarak tanımlar. Bıjikyan'ın bu iddiasının doğru olmadığı caminin vakıf kayıtlarından anlaşılmaktadır. Bu kayıtlardan, 1486-1523 tarihleri arasında inşa edilmiş olduğu anlaşılan Mescid-i Hacı Kasım'ın harap olması nedeniyle, mescidin yıktırıldığı yerine bugünkü mevcut kagir caminin yaptırıldığ anlaşılmaktadır (Tuluk ve Düzenli, 2010, s. 69-70). Bijişkyan'nın yaşadığı dönem dikkate alındığında yeni yapıyı görmüş olması gerekse de bahsettiği yapının hangisi olduğu açık değildir.

Gülbahar Hatun Külliyesi: Trabzon'a valilik yapan Yavuz Sultan Selim'in, annesi adına inşa ettirdiği yapı kompleksi sur duvarlarının dışında, bugün aynı isimle anılan mahallede yer almaktadır. Aşık Mehmed (Ak, 1997, s. 406-407) külliyede yer alan yapıları; kurşun kaplı, tek parça kubbeli cami ve türbe, taşlarının bir sırası siyah bir sırası beyaz taşlı düzgün minare ile caminin önündeki avlunun kuzey ve batı yönünde yüksek hücreli medrese, caminin kıble tarafında matbah, fırın, misafirlerin hayvanları için ahır, mutfak zahirelerini koymak için mahzen ve kiler, matbahın bitişiğinde fakir öğrencilere hizmet veren 
yemekhaneler, yine caminin batı kısmında fakir ve yetim çocuklara Kuran öğretilen yer olarak tanımlar.

Aşık Mehmed'in (Ak, 1997, s. 406-407), Cami-i Hatuniyye olarak adlandırdığ1 caminin, ş kitabesinde H.952 (1545/46) tarihi yazdığını söyler ancak hemen ardından bu tarihin bu tarih caminin yapıldığı yılı değil tamir edildiği yılı ifade ettiğine dair düşüncesini açılar. Külliyenin bulunduğu alanı bir tepenin üzerinde ve iki kapısı olan surlarla çevrili olarak tanımlar ve kendi ifadesiyle "muhteşem" kubbeli bir camiyi de bu alanın orta yerine yerleştirir. Bijışkyan'nın (1998, s. 100) burada "surlarla çevrili" betimlemesi ifade olarak yanlıştır. Külliye sur dışında ve batı varoşlarında yer almaktadır. Seyyah muhtemelen, külliyenin etrafında günümüzde mevcut olmasa da eski fotoğraflardan varlı̆̆ tespit edilen duvardan bahsetmektedir. Külliyede yer alan yapılara, Aşık Mehmed'in (Ak, 1997, s. 406407) tanımladıklarını tekrar ettiği gibi bazı eklemeler de yapar. İmaretin önünde şadırvanın ve öğrencilere mahsus olan odalarla çevrili geniş bir meydanın, güneyinde mezarlığın, doğuda Yavuz Sultan Selim'in annesinin gömülü olduğu ve onun adını taşıyan, kitabesinden H.911 (1505/1506) tarihini okuduğu türbenin yer aldığını belirtir. Aşık Mehmed'in (Ak, 1997, s. 406-407) de bahsettiği mutfak ve fırın hakkında Bijışkyan (1998, s. 101), daha önceki ziyaretinde fakirlere ve medrese öğrencilerine günde iki kere yemek çıkarıldığından ancak ziyaret ettiği dönemde bu uygulamanın olmadığını aktarır. Bıjışkyan imaret binasının tarihi hakkında bilgilerde vermeye devam eder ve elinde herhangi bir kitabe olmadığını da belirterek yapıyı eski bir manastıra benzetir. Ayrıca Rumlardan aldığını belirttiği bir bilgiyi aktararak, İmaret'ten önce St. Jan adında bir kilisenin olduğundan ve daha sonra camiye çevrildiğini, 320 yıl önce de Valide Sultanın ruhuna tekkeye çevrilmiş olduğunu söyler.

Cami-i Süleymân Bey/Kabakmeydanı Camii: Yapının ismine ilk kez Aşık Mehmed'in (Ak, 1997, s. 407) Menazıru'l-avalim'in de Cami-i Süleymân Bey ismi ile rastlanır. Aşık Mehmed (Ak, 1997, s. 407) yapının bulunduğu yere dair bilgi verir ve Cami-i Hatuniyye'nin (Gülbahar Hatun Camii) batısında ve 1 mil (yaklaşık 1,9km) uzağında, bugünde benzer şekilde anılan, Kabak Meydanı (Kavak Meydanı) olarak anılan "geniş yerin" batı ucunda yer aldığını belirtir. Aşık Mehmed (Ak, 1997, s. 407), küçük bir yapı olduğunu belirttiği yapının banisi olarak Trabzon' da sancak beyliği yapmış olan Süleyman Bey adlı bir hayırseveri işaret eder ve inşa tarihine ilişkin de "yapılışı 30 yılı aşmamış belki de 30 yıl da olmamıştır" der. Bu durumda seyyahın metnini kaleme aldığı tarih dikkate alınırsa yapının yaklaşık 1560'lı yıllarda inşa edildiği söylenebilir. Yapıya değinen diğer seyyah Bijışkyan'dır. 19.yy da yazdığı seyahatnamesinde Kavak Meydan'ı tanımlarken "Kabak Meydanı denilen geniş alan batı taraftan başlar... Burada bir Türk ve Süleyman Bey'in yaptırdığı söylenen Kabakmeydanı Camii vardır" ifadesi ile yapıya da değinir (Bijışsyan, 1998, s. 85). Yapının günümüzdeki izleri sürüldügüunde Aşık Mehmed'in ifade ettiği gibi Kavak Meydanı'nın batı ucunda bugün bulunan İncirlik Camii'nin "Cami-i Süleyman Bey"in yerine yapıldığı söylenebilir. (Tuluk ve Düzenli, 2010, s. 73-74)

Cami'-i Erdoğdı Bey (Erdo ̆̆du Camii): Yapının ismine ilk kez Aşık Mehmed'in (Ak, 1997, s. 407) metninde "Cami-i Hatuniye'nin güneyinde yarm milden fazla mesafedeki Tekfur Saray Mahallesi'nde Cami-i Erdoğdu Bey" ifadesi ile rastlanmaktadır. Yapının, içerisinde üç vakit namazı kılınmasına karşın vakfı olmadığından harap olmuş, kare planlı küçük bir mescidin yerine "hayırsever" Erdoğdu Bey tarafından H. 985'den (1577-78) yeniden inşa edildiğini yazar. Erdoğdu Bey'in harap mescidi temelinden yıkıp, çevresindeki araziler de alarak Aşık 
Mehmed'in (Ak, 1997, s. 407) "yüksek ve uzunca" olarak tanımladığı camiyi inşa ettirdiğini, yontulmuş taşlardan bir minare ile cami içinde minber ve müezzin mahfili ilave edildiğini belirtir.

İskender Paşa Camii: Günümüzde İskender Paşa Mahallesi'nde, Aşık Mehmed'in (Ak, 1997, s. 407) tanımı ile surların doğusundan 1 mil (1.9 km) uzakta, bugün Atatürk Alanı olarak anılan Gavur Meydanı'nın doğu ucunda yer alır. Şakir Şevket (2001, s. 132-133 ) caminin Yavuz Sultan Selim'in Trabzon'daki sancak beyliğinden sonra yerine geçen İskender Paşa tarafından H.940 (1533-1534) yıllarında medresesi ile birlikte yaptırıldığını söyler. Caminin hemen yanı başında yaptırılan çeşmeye de Kavak Meydanı Mahallesinden su getirildiğine değinir. Aşık Mehmed (Ak, 1997, s. 407) yapının mimarisine ilişkin "kurşun örtülü ve tek parça kubbeli taştan yapılmış bir bina" olduğundan, minaresinin ise tuğladan düzgün bir şekilde yapıldığı bilgisini verir. Yapının kuzey duvarı önündeki bugün bulunmayan birkaç odalı medresesinin de varlığına Aşık Mehmed'te (Ak, 1997, s. 407) değinir. Şakir Şevket (2001, s. 134), İskender Paşa Medresesi'nin zaman geçtikçe harap olmasına karşın, yaklaşık 1875'lerde, dönemin Trabzon Gümrük Müdürü Trabzonlu Rahman Efendi'nin gayretleriyle tamir edildiğini, gelirin de tamamen medreseye bağışlanmak üzere iki tane mağaza inşa ettirildiğinden bahseder.

Karabaş Cami-i Şerifi: Yapı günümüzde ayakta olmadığından, inşa tarihine ilişkin kaynaklarda önemli ayrılıklar bulunmaktadır." Ş1 Şakir Şevket (2001, s. 75, 170) "Tophane Hamamı'nın doğu tarafında, Mumhaneönü İskelesi'nin batı tarafında ve Trabzon kalesinin dibinde" şeklinde bugünkü Pazarkapı Camisi'yle hemen hemen aynı mahalde yerini tanımlar. Ayrıca, bir rivayete dayandığını da belirterek, fetihten sonra terk edilen eski bir kilise Fatih Sultan Mehmet tarafından bir vakfa atfedilerek camiye dönüştürüldüğünü ve yapıya Karabaş Camii denildiğini ifade eder. ${ }^{32}$ Uzun bir süre kullanılmayan ve harap olmuş yapı Kutubzade Şeyh Hacı Abdü'l-Hamid Efendi ve Dervişzade Hacı Mehmed Efendi'nin yardımları ile tamir edildiğini ve Abdullah Paşa zamanına kadar kullanıldığını belirtir. Abdullah Paşa tarafından Pazar Kapusu Cami-i Şerifi yaptırılırken, Karabaş Camisinden çıkarılan taş direklerin Gavur Meydan'ında yaptırdığı şadırvana konulduğunu açıklayan ifadesinde de Pazarkapı Camii'nin inşası sırasında bu yapının yıkıldığı anlaşılır.

Pazar Kapusu Cami-i Şerifi: Karabaş Camii'ni anlatırken bahsedilen yapı hakkında yalnızca Şakir Şevket (2001, s. 170) bilgi verir. Bahsi geçen yapı bugünkü Pazarkapı Camii'nin inşası için yıkılan eski camidir. "Pazar Kapusu Cami-i Şerif"in de Karabaş Camii'nin yerine Abdullah Paşa tarafından yaptırıldığı anlaşılmaktadır. Şakir Şevket'in (2001, s. 170) aktardığına göre yapı tamamen yanmış ve yıllar sonra Belediye Reisi Ali Rıza Efendi'nin tarafından tamir ettirilmiş ve tekrardan kullanılmaya başlanmıştır. 1793 yılında inşa edilen bu yapı 1988 yılında yıkılmış ve yerine bugün kullanılmakta olan Pazarkapı Camii inşa edilmiştir.

Ahi Evren Türbesi: Boztepe'de, Şeyh Hacı Hakkı Efendi'nin yaptırdığı Ahi Evran Dede türbesi bulunmaktadır. Yapıya yalnızca, detalı olmasa da Şakir Şevket (2001, s. 116-117) değinir. Seyyah, eserini yazmadan 6-7 sene önce, gayrimüslimlerin türbeye dikilmiş olan

\footnotetext{
31 Yapının inşa tarihine ilişkin değerlendirme için bknz (Tuluk ve Düzenli, 2010)

${ }^{32}$ Fethin ardından Aşağıhisar Surları içerisinde camiye dönüştürülmüş iki kilisenin varlığı bilinmektedir. Bu yapılar St. Andrea Kilisesi (Molla Siyah Camii) ile fethin ardından camiye dönüştürülmüş St. John Theologos Kilisesidir. Yapının, Şakir Şevket'in Karabaş Camii'ne ilişkin “camiye çevrilmiş eski bir kilisedir” ifadesindeki kilise olup olmadiğ
} 
fidanları kırdığını, türbe için yaptırılan su kuyusunu taş ile doldurdukları belirtilir. Yapıya verilen bu zararlardan dolayı Müslümanların ayaklandığını fakat yine "önemli" olarak betimlediği Müslüman kişilerin araya girmesiyle olaylar yatıştırılıp, kırılan fidanların yerine yeni fidanlar dikilerek Ahi Evren Türbesinin etrafı daha da güzelleştirildiğinden bahseder.

\section{Hamamlar}

Seyyahlar metinlerinde, genel olarak bilgi verdikleri dini yapılar dışında, her medeniyet için önem taşıyan ve toplumun sıklıkla kullandığı hamamlara da yer vermişlerdir. Aşık Mehmed (Ak, 1997, s. 407) kentte yedi adet hamamın varlı̆̆ından bahseder. Bunlardan ilki Aşağıhisar kapısı yakınında yer alan, erkek-kadınlara ayrı ayrı hizmet verildiğinden dolayı halk tarafından Çifte Hamam olarak isimlendirilen hamamdır. Bijişkyan (1998, s. 95-96) hamamı büyük kısmının yeraltında olan "garip bir bina" olarak tanımlar ve hamamın sonradan ikiye ayrıldığını ve Çifte isminin verildiğinden bahseder. Aşık Mehmed'in (Ak, 1997, s. 407) detaylıca bahsettiği ikinci hamam, Kule'nin (Yukarıhisar) kuzey duvarına yakın olduğundan dolayı halk tarafından "Kule Hamamı" olarak isimlendirilen yapıyı, eşsiz bir yapı olarak nitelendirir ve gayrimüslimler tarafından yapıldığını iddia eder. Bijışkyan'da (1998, s. 93) aynı yeri işaret ederek, hamamın İçkale'de yer aldığını ifade eder. Aşık Mehmed (Ak, 1997, s. 407) bu iki hamam dışındaki beş hamamın daha ismini verir. Cami-i Hatuniyye'nin yakınlarında "zarif bir yapı" olan İmaret Hamamı, Aşağıhisar'da, sur içinde, Aşağı Hisar Hamamı, kentin işlek pazarlarının yakınında tıpkı Çifte Hamam gibi hem erkeklere hem de kadınlara hizmet eden İskender Paşa Hamamı diğer bir deyişle Bazar Hamamı, Yeni Cuma ve Gavur Meydanı mahalleleri arasında Gavur Hamamı ve genellikle kapalı olan ve küçük olmasına rağmen eşinin zor bulunacağı ifade ettiği Tekfur Saray Hamamı'nın isimlerini zikreder.

\section{Köprüler}

Kentin çeperlerini tanımlayan vadiler ve bu vadiler üzerinde yer alan, sur içi ve dışını bağlayan köprülerin varlığı Trabzon için önemlidir. Kent sur dışına; doğu, batı ve güney varoşlarının yerleşime ve ulaşıma uygun kıyı ya da düz alanlarına yayılırken, güneyde dağlar, doğuda ise yine büyük bir vadinin, Değirmendere Vadisi'nin sınırlayıcıllğı ortaya çıar. Aşı1k Mehmed (Ak, 1997, s. 406) sur kapılarından "Bab-ı Debbağhane"yi ve "Bab-ı Zindan"1 açıklarken bugünkü Tabakhane Köprüsü ile Zağnos Köprüsü'nün varlığına da işaret eder. Ortahisar ile Atapark arasında ulaşımı sağlayan, Zağnos Köprüsü'ne ilişkin, Aşık Mehmed (Ak, 1997, s. 406) özellikle Bab-1 Zindan'ı açıkladığı cümlede ilginç bir bilgiye değinir: “...Bu kapıdan da yine taştan yapılmış 3 ziralık kısmı ahşab ile kaplı büyük bir köprüden Bab-ı Zağanos'a geçilir. Bu köprü aşağıda anlatılacak olan sur içinde sayılır ve Bab-ı Zindan'dan Babı Zağanos'a kadar bu köprüye bitişik olarak sur duvarı uzanır." Aşık Mehmed'in yapmış olduğu tanımdan, Zindan Kapısı'nı Zağnos Kapısı'na bağlayan köprünün "3 ziralık kısmı"nın ahşap kaplı olma hali ile günümüzdeki görünümünden uzak olduğu anlaşılmaktadır (Tuluk, 2010 s. 35). 19.yy.ın başlarında kenti ziyaret eden Bijişkyan'da (1998, s. 96) kenti çevreleyen vadilerden bahsederken köprüye değinir ve Aşı Mehmed gibi sur kapıları ile yerini tanımlar. Geniş ve derin vadiyi geçen yüksek bir yapı olduğunu belirttiği köprünün, Aşık Mehmed'in tanımını da tamamlayacak şekilde, iki yandan yarıya kadar taş, orta kısmının ise "tahta" olarak inşa edildiğini belirtir. "İşkeleboğ Deresi" üzerindeki köprünün savaş sırasında ayağa kaldırılarak kalenin savunması sağlandığını, belirtir ki buradan da şimdiki köprünün yerine eskiden surlarının girişinde kapı görevi gören açılır kapanır bir köprü olduğu anlaşılır. Nitekim 19.yy. sonunda Şâkir Şevket'te (2001, s. 64) Zağnos Köprüsü'nün orijinal ahşap biçimini kaybettiğini, sabit ve kagir yapı olduğunu ve belirtir.

SEFAD, 2020; (43): 435-466 
Surlarla çevrili alanı doğu-batı istikametinde sıkıştıran vadilerden ikincisi, doğuda yer alan Tabakhane Vadisidir. Aşık Mehmed (Ak, 1997, s. 406), Tabakhane Köprüsü'nü suyu büyük vadiden gelen, küçük bir nehir ve üzerinde taştan yapılmış büyük bir köprü olarak tanımlar. Bijişkyan'ın (1998, s. 100) hemen Tabakhane Kapısı'nın önüne yerleştirdiği köprüye dair yaptı̆̆ 1 "geniş köprü" ifadesi daha sonraki açıklamaları ile anlam bulur. Seyyah bu köprünün altından Kuzgundere isimli derenin, üzerinden ise Justinianos kanalından gelen suyun geçtiğini ifade eder. Bijişkyan'ın bu ilgi çekici ifadesi günümüzde sur içini doğu yerleşim alanlarına bağlayan bir köprü görevi gören, seyyahlar tarafından "geniş" ve "büyük" olarak tanımlanan Tabakhane Köprüsü'nün aslında Roma dönemi bir su kemeri olduğunu düşündürmektedir. Nitekim günümüzde ki mevcut izlerden de, Tabakhane Köprüsü'nün boyuna bir dilatasyonla birleşen iki ayrı köprüden meydana geldiği anlaşılmaktadır (Karpuz, 1990, s.30; Tuluk 2010, s. 36).

Sur dışında kentin doğudaki sınırını çizen Değirmendere Vadisi ve köprüsüne ilişkin ise Bijişkyan (1998, s. 111), Gümüşhane'nin yakınından gelen orta büyüklükte bir çay varlığına, üzerinde ise "beş gözlü yüksek ve büyük bir kagir köprü̈" bilgisini verir. Seyyahın bahsettiği "beş gözlü" köprü 1890'da yaşanan sel sonucu yıkılmış, 1891 tarihinde Nemlizadeler tarafından günümüzde de mevcut olan "dört gözlü" köprü inşa edilmiştir.

\section{Sivil Yapilar}

Sur içinde veya dışında halkın oturduğu konutlara veya bu konutların oluşturduğu dokuya değinmezken, yalnızca Bijişkyan (1998, s. 98-99, 110), muhtemelen "saray" niteliğindeki olmaları nedeniyle iki yapı hakkında bilgi verir. Bunlardan ilki "Paşasarayı"dır. Günümüzde yerine dair net bir bilgi olmayan yapıya dair seyyah; Aşağıhisar bölgesinde yer aldığı ve güneyinde İmaret Kapısı'nın bulunduğu bilgisini verir. Bijişkyan'nın (1998, s. 9899) İmaret Kapısı ile kurduğu ilişki ile birlikte alana dair vermiş olduğu Ortahisar ile aynı yükseklikte, denize nazır bir konumda olduğu bilgisi dikkate alındığında yapının yeri ile ilgili bazı yorumlar yapılabilir. "Paşasarayı" ifadesi, yine seyyahın bahsettiği "Güzel Saray" veya "Üçüncüzâde Sarayı" haricinde kayıtlarda geçen Saray-1 Atik, Tekfur Sarayı, Saray-1 Amire gibi saray isimlerinden herhangi birini tanımlamaz. Tekfur Saray; tahrir defterlerinde doğu varoşlarında Mahalle-i Tekfur Saray olarak geçen, bugün Erdoğdu Mahallesi olarak anılan bölgededir. Kayıtlarda geçen ifadelere dayanarak ${ }^{33}$ Saray-1 Amire isminin de yine Saray-1 Atik ile aynı yeri tanımladığı iddia edilebilir. Bugün Aşağıhisar bölgesinde bir sokak isminde hala rastladığımız Sarayatik Camii Sokak ifadesi ile bu sokağın konumu dikkate alındığında Bijişkyan'ın "Paşasarayı" için yaptığı yer tanımı ile örtüştüğü söylenebilir.

Bijişkyan (1998, s. 110) "Güzelhisar" olarak isimlendirdiği ikinci yapıyı 1740 tarihinde Üçüncüoğlu Ahmed Paşa'nın yaptırdığını belirtir. Batıda yüksek kayanın üzerinde, doğudan Lazistan'a, batıdan Yoros'a ve kuzeyden denize nazır bir konumda yer aldığını söylediği sarayı, "surla çevrili, yüksek ve güzel manzaralı saray" olarak tanımlar. Seyyah bu yapının mimarisine ilişkin de bilgi verir. Ona göre, önünde geniş bir meydan ve de bahçe bulunana iki katlı yapı, kuzey ve güney cepheleri ile iki kısma ayrılır ve alttan tepeye kadar çok sağlam bir destek duvarının üzerine oturtulmuştur.

\footnotetext{
${ }_{33} 1523$ tarihli Tahrir Defteri'nde, “Mahalle-i Mescid-i Hüseyin Aga Ki Serhazin Büd Der Nezd-i Saray-1 Amire" ile vakıf kaydında yer alan "Saray Atik mahallesindeki Hüseyin Ağa Camii Vakfı" ifadeleri çakıştırıldığında Saray-1 Atik ile Saray-ı Amire'nin aynı yeri tanımladığı düşünülebilir. Detaylı bilgi için bknz. Üstün Demirkaya (2014).
} 
Tablo 1. Seyyahların metinlerinde geçen mahalleler, limanlar ve yapılar

\begin{tabular}{|c|c|c|c|}
\hline & AŞIK MEHMED & MINAS BIJIŞKYAN & ŞAKİR ŞEVKET \\
\hline \multirow{22}{*}{ 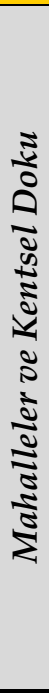 } & $\begin{array}{l}\text { Surlar (Yukarıhisar, Ortahisar, } \\
\text { Aşağıhisar) }\end{array}$ & Surlar (Yukarıhisar, Ortahisar, Aşağıhisar) & Surlar (Yukarıhisar, Ortahisar, Aşağıhisar) \\
\hline & Boztepe & Boztepe & Boztepe \\
\hline & Yeni Cuma & Yeni Cuma & \\
\hline & & Sotka & Eksotha \\
\hline & & Aya Vasil & Ayvasıl \\
\hline & & Aya Filippo & Ayafilbo \\
\hline & & Ayasofya & Ayasofya \\
\hline & & Kabakmeydan1 & Kabak Meydanı \\
\hline & & Gavur Meydanı & Gavur Meydanı \\
\hline & & Faros & \\
\hline & & Çömlekçi & \\
\hline & & Tekke & \\
\hline & & Kemerkaya & \\
\hline & & Tuzluçeşme & \\
\hline & & Zeytinlik & \\
\hline & & Aya Kiryaki (Tespit Edilemedi) & \\
\hline & & Aya Mam (Tespit Edilemedi) & \\
\hline & & Aya Ğorğor (Tespit Edilemedi) & \\
\hline & & Aya Yorgi (Tespit Edilemedi) & \\
\hline & & Hiristos (Tespit Edilemedi) & \\
\hline & & & Mumhaneönü \\
\hline & & & Meryem Ana (Tespit Edilemedi) \\
\hline \multirow{8}{*}{$\frac{\frac{1}{5}}{\frac{5}{5}}$} & & Moloz & Moloz \\
\hline & & Çömlekçi & \\
\hline & & Yazlik Liman & \\
\hline & & Kanida & \\
\hline & & Tuzluçeşme & \\
\hline & & Taşdirek & \\
\hline & & Kemerkaya & \\
\hline & & Mumhaneönü & \\
\hline \multirow{17}{*}{$\frac{\grave{d}}{\stackrel{D}{ \pm}}$} & Yenicuma Camii & Evgenios Kilisesi (Yenicuma C.) & \\
\hline & Ortahisar Fatih Camii & Altınbaş Kilisesi (Ortahisar Fatih C.) & Ortahisar Fatih Camii \\
\hline & Ayasofya Camii & Ayasofya Kilisesi & Ayasofya Camii \\
\hline & & Anne Kilisesi & \\
\hline & & Kızlar Manastırı & \\
\hline & & Aya Vasili Kilisesi & \\
\hline & & Amenapırgıç Manastırı (Kaymaklı M.) & \\
\hline & & Philip Kilisesi(Esentepe Kudrettin C.) & \\
\hline & & Grek Kilisesi (Tespit Edilemedi) & \\
\hline & & George Rum Kilisesi (Tespit Edilemedi) & \\
\hline & & Kırbatal Şapeli (Tespit Edilemedi) & \\
\hline & & Sava Kilisesi (Tespit Edilemedi) & \\
\hline & & Asduadzadzin Kilisesi (Tespit Edilemedi) & \\
\hline & & Çarhapan Kilisesi (Tespit Edilemedi) & \\
\hline & & Surp Ohannes (Tespit Edilemedi) & \\
\hline & & Surp Oksent Kilisesi (Tespit Edilemedi) & \\
\hline & & Aya Ğorğon Kilisesi (Tespit Edilemedi) & \\
\hline \multirow{11}{*}{ 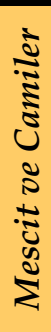 } & Gülbahar Hatun Külliyesi & Gülbahar Hatun Külliyesi & \\
\hline & İskender Paşa Camii & & İskender Paşa Camii \\
\hline & Süleyman Bey Camii & & \\
\hline & Erdoğdu Bey Camii & & \\
\hline & & Çarşı Camii & \\
\hline & & Kabakmeydanı Camii & \\
\hline & & Boyahane Mescidi & \\
\hline & & Tavanlı Camii & \\
\hline & & & Karabaş Camii \\
\hline & & & Ahi Evren Türbesi \\
\hline & & & Pazar Kapusu Camii \\
\hline \multirow{7}{*}{$\begin{array}{l}\frac{1}{3} \\
\frac{1}{5} \\
\frac{1}{3} \\
\frac{1}{2}\end{array}$} & Çifte Hamam & Çifte Hamam & \\
\hline & Kule Hamamı & & \\
\hline & İmaret Hamamı & & \\
\hline & İskender Paşa Hamamı(Bazar Hamamı) & & \\
\hline & Gavur Hamamı (Tespit Edilemedi) & & \\
\hline & Aşağıhisar Hamamı (Tespit Edilemedi) & & \\
\hline & Tekfur Saray Hamamı (Tespit Edilemedi) & & \\
\hline \multirow{4}{*}{ 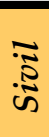 } & & Güzelhisar & \\
\hline & & Paşasarayı (Tespit Edilemedi) & \\
\hline & & & \\
\hline & & & \\
\hline
\end{tabular}




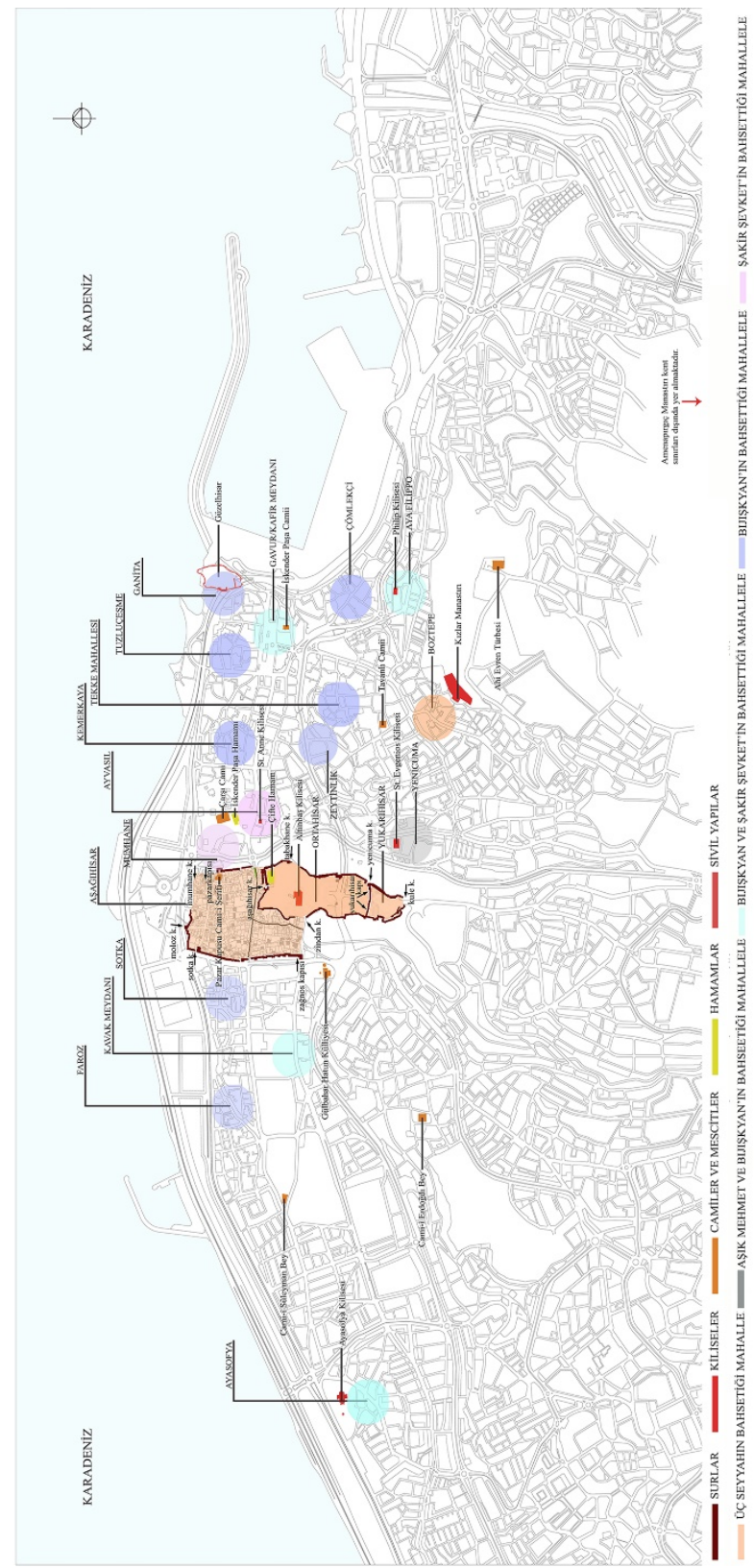

Şekil 1. Seyyahların metinlerinde geçen mahalleler ve yapılar 


\section{DEĞERLENDIRME VE SONUÇ}

Coğrafik ve stratejik konumunun sağladığı, doğu ve batı arasında ticari ve askeri, kara ve deniz bağlantısının merkezi olma rolü ile Trabzon, tarih boyunca sayısız seyyahı kendine çekmiştir ve ziyaretçisi olan her seyyah tarafından değişik yönlerden ele alınmıştır. Bu bilgi külliyatının içinde kentin tarihine olan yaklaşımda, kendi memleketini anlatan seyyahların verdikleri detaylı bilgiler dikkate değerdir. Kendi memleketleri olan Trabzon'u anlatan; Aşık Mehmed (16.yy), Minas Bijı̧şkyan (19.yy) ve Şakir Şevket (19.yy) Trabzon doğumlu, İsmail Safa'nın (19.yy) ise babası Trabzonludur. Bijıskyan, bu dört seyyah arasındaki tek gayrimüslimdir. Şakir Şevket'in metni şehir tarihini şeklinde kaleme alınmışken, diğer eserler tam anlamıyla birer seyahatname özelliği taşımaktadır. İsmail Safa'nın manzum eseri kentin fiziksel dokusu konusunda net bilgiler vermediği için çalışma kapsamında kullanılamamıştır.

Seyyahlar; kentin tarihi, coğrafi koşulları, dokusu, toplumu hakkında, yazılı ve yazısız farklı kaynakları da referans vererek, oldukça detaylı bilgiler sunmaktadırlar. Özellikle "Trabzon" isminin kökeninine dair farklı kaynaklara atıfta bulunurlar. Seyyahlar yaşadıkları dönem itibariyle, ağırlıklı olarak Osmanlı fethi, fetih sonrası uygulamalar, nüfus, surlar, ilk yerleşim, kent kapıları, sur içi-varoşlar ve bu bölgelerdeki cami, kilise manastırlar ile birlikte kentin limanları ve çarşısı hakkında detaylı bilgiler vererek dönemsel panorama çizmektedirler. Seyyahların kimlik bilgilerini sorgulamak ise kenti ele alışlarını bütüncül olarak anlamak açısından önemlidir. Nitekim seyyahlar arasında inanç farklılığ metinlerinden okunabilmektedir. Aşık Mehmed kilise ve manastırlara neredeyse hiç değinmezken, Minas Bıjışkyan'da gayrimüslim olmasından kaynaklanan bir bakış açısı görülmektedir. Bijışkyan, Aşık Mehmed'in aksine, manastır-kiliselere daha fazla önem verdiği anlaşılmaktadır. Ayrıca Bıjışkyan, mevcut haliyle Müslüman yapısı olmasına karşın, pek çok yapı için, çoğunlukla "zorlama" olarak ifade edebileceğimiz, yapıdan önceki yapı veya inşasının daha eskiye dayanabileceği irdelemelerini sıklıkla yapmaktadır. Aşık Mehmed ve Şakir Şevket ise tam tersi şekilde gayrimüslimlerin Müslüman yapılara verdiği zarardan bahsetmektedir.

Kendi dönemlerinin bilgi toplama ürünleri olarak oluşturdukları metinlerinde, seyyahlar gördüklerini kendi algıladıkları biçimde kâğıda aktarsalar da, sahip oldukları bilgi birikimleri, düşünceleri ve mesleki özellikleri daha da önemlisi içinde bulundukları kültürel ortam kent ile ilgili değerlendirmelerinde kendisini gösterir. Kısacası bu öznel değerlendirmelerin bazı ön yargıları taşımaları olağandır. Çoğu tartışmalı yapı hakkında verdikleri bilgiler ile kaynaklarda isimleri hiç geçmeyen veya geçse dahi fiziksel özelliklerinde bahsedilmeyen yapılara ilişkin kendi bahşettikleri önem derecesinde detaylı denilecek şekilde bahsetmişlerdir. Verilen bu detayda çoğu kez mekanı deneyimlemeleri, pek çok hikaye dinlemiş olmaları gibi yerel kültürün etkileri takip edilmektedir. Yukarıda da belirttiğimiz gibi eksiklikleri ve kendi içlerinde de zıtlıkları barındırmalarına karşın, seyyahların özellikleri ve dönemin olayları-yaygın söylemleri tahlil edildiğinde, verilen bilgiler, yapılacak olan çalışmalarda vazgeçilmez kaynaklar olma özelliğini korumaktadırlar.

\section{SUMMARY}

Travelogues are quite valuable for their evaluations on topics related to city structures, epitaphs, streets, bazaars and mahalles, demographic structure and daily life of the people, and they are particularly valuable in cases where archive documents or written and unwritten sources are insufficient. Since the 17th and 18th centuries, travellers have

SEFAD, 2020; (43): 435-466 
gravitated towards different geographies and certainly toward the formerly Ottoman territories to gain knowledge about the militaristic and economic expansion of the Western world. Trabzon has become a notable location on the route of many travellers and earned their wonderment due to its geographical location and the harbour market place setting on the cross section of trade routes. There is a wide variety of travelogue literature that mentions Trabzon, and the earliest text to do so is definitely "Anabasis" by Xenophon in 400 BC. Travellers have been curious and taken notes about settlements, trades, road and transportation, social life, population and social structure of this place, while informing the world about geographical structure, flora, climate and natural life of the city. It is best advised to not ignore that a lot of clarity to many unknowns regarding this place has been granted by these texts, which undoubtedly contain rich material in terms of city history and have been stuck between the prejudices of the writer and what they had seen. In addition, it should be kept in mind that the findings of these travellers about the place may not always be unique and direct quotations from previous works may be included; sometimes, the findings may be variations of each other. Within this context, it is aimed that Trabzon be viewed from the perspective of the travellers who studied the place in greater depth and experienced Trabzon as locals compared to the observations of foreign visitors. The text reading method has been adopted in this study. The three texts we read called Menazırü'lavalim written by Aşık Mehmed in the 16th century and the works of Per Minas Bijışkyan's Pontus History and Şakir Şevket's Trabzon History, both of them written in the 19th century. The Trabzon-born Aşık Mehmed (16th century), Minas Bijşkyan (19th century) and Şakir Şevket (19th century) and İsmail Safa (19th century) have conveyed information concerning the history, structures, epitaphs, streets, bazaar and mahalles, demographic structure and daily life of the people of the city. Their notes are evaluated and compared and were found to sometimes contradict each other and sometimes match up or complete each other. Bijışkyan is the only non-Muslim among these four travellers. The text of Şakir Şevket is about the city history, whereas all other works are characteristically travelogues. The poetic work of İsmail Safa has not been included in the study because it did not give clear information on the urban tissue of the city. Evaluation of the information included in the travelogues is essentially inclined towards understanding the urban tissue of the city. Therefore, texts of these travellers have been discussed with a focus on the location of the city, its harbour and its religious, military, commercial and civil structures which are a part of the city's urban tissue. Furthermore, there is a focus on mahalles, which are complementary of this urban tissue. The information provided by the travellers has been discussed under the following headings: The Name of Trabzon, Geography of the City and First Settlement, Ottoman Conquest, Walls and Defense, Neighbourhoods and Urban Texture, Ports, Religious Buildings, Public Works and Civil structures. All the information obtained from the texts was evaluated together, and the structure and place names identified under the titles were tabulated according to the travellers. In addition, the descriptions of three travellers who described their hometown have been visualised using a map. The physical texture of the city as studied through the perspective of these travellers has been revealed by overlapping narratives. The information given by these three travellers was collectively evaluated; consequently, it was noted that although Aşık Mehmed and Şakir Şevket predominantly draw attention to Ottoman urban texture, P. Minas Bijışkyan described the same era as that described by Şakir Şevket but with an emphasis on the nonMuslim structures of the Ottoman and pre-Ottoman period. Because travellers narrate their 
own homeland, they most particularly mention their own experiences beyond mere observation and speculation. However, the era in which these travellers lived and the information about their identity (e.g., religious, political and vocational) can be traced through their texts. Although it may first seem that the texts contain personal evaluations, each traveller has conveyed new information regarding the urban tissue of the city owing to the differences in the cultural environment around them. The study of this place has been enriched by common findings as well as the differences in terms of the structure, location or situation reported by these travellers. Within this context, although travellers have narrated their own homeland through their own life perspective, this has enabled us to reach different stories and question what seems to be correct. Furthermore, they have provided important information with detailed description regarding many structures and locations. This information has been missing and was not mentioned in many sources. 


\section{KAYNAKÇA}

Ak, M. (1997). Menazırü'l-avalim (tahlil-metin) (Yayımlanmamış doktora tezi). İstanbul Üniversitesi, İstanbul.

Ak, M. (Ak, 1990). Aşık Mehmed ve Menazırü'l-avalim (Yayımlanmamış yüksek lisans tezi). İstanbul Üniversitesi, İstanbul.

Aydın, B. (2012). XVI. yüzyıl Osmanlı seyahatnâmeleri hakkında bir değerlendirme. Osmanlı Araştırmaları/ The Journal of Ottoman Studies, (XL), 435-451.

Aygün, N. (2005). Onsekizinci yüzyılda Trabzon'da ticaret. Trabzon: Serander.

Belge, H. (2018). Trabzon mezarlıkları ve mezar anıtları (1926-2018) (Yayımlanmamış yüksek lisans tezi). Karadeniz Teknik Üniversitesi, Trabzon.

Bijıskyan, P. M. (1998). Pontus tarihi/tarihin horona durduğu yer Karadeniz (H. D. Andreasyan, Çev.). İstanbul: Çivi Yazıları.

Bryer, A. ve Winfield, D. (1985). The Byzantine monuments and topography of the Pontos. Washington.

Çelik H. (2017). İsmail Safa'nın edebiyat nazariyesine dair çalışmaları (Yayımlanmamış yüksek lisans tezi). Trakya Üniversitesi, Edirne.

Kallek, C. (2005). "Mil”. TDV İslam Ansiklopedisi, 30, 53-54.

Karpuz, H. (1990). Trabzon. Ankara: Kültür Bakanlı̆̆1 Yayınevi.

Kurnaz, M. (1994). Trabzon'da 35 vakfa ait notlar. İ. Hacıfettahoğlu (Ed.), Trabzon fetih yıllığı 1994 (s. 74-105). Ankara: Atlas Yayıncilik.

Lowry, H. W. (2005). Trabzon şehrinin İslamlaşması ve Türkleşmesi (1461-1583). İstanbul: Boğaziçi Üniversitesi Yayınevi.

Miller, W. (2007). Son Trabzon İmparatorluğu. İstanbul: Heyamola Yayınları.

Şevket, Ş. (2001). Trabzon tarihi / ilk Türkçe şair tarihi. İ. Hacıfettahoğlu (Ed.) Trabzon: Trabzon Belediyesi Kültür Yayınları.

Texier, C. (2002). Küçük Asya coğrafyası, tarihi ve arkeolojisi (A. Suat, Çev.) Ankara: Enformasyon ve Dokümantasyon Hizmetleri Vakfi.

Tuluk, Ö. İ. (2010). Osmanlı dönemi Trabzon'unda mimari yapı kültürü. Ö. İ. Tuluk ve H. ̇̇. Düzenli (Ed.), Trabzon Kent mirası, yer-yapı-hafıza (s. 55-92). İstanbul: Klasik Yayınları .

Tuluk, Ö. İ. ve Düzenli, H. İ. (2010). Yitik mirasın izinde: Trabzon'da Osmanlı cami ve mescitleri (1461-1583), İ. Tuluk ve H. İ. Düzenli (Ed.), Trabzon Kent mirası, yer-yapı-hafıza (s. 31-53). İstanbul: Klasik Yayınları.

Uspenski, F. I. (2003). Trabzon tarihi (kuruluşundan fethine kadar) (E. Uzun, Çev.) Trabzon: Kendi Yayını.

Usta, V. (1999). Anabasis'ten Atatürk'e seyahatnamelerde Trabzon. Trabzon: Serander Yayınları.

Usta, V. (2013). Trabzon'dan söz eden seyahatnameler hakkında bir değerlendirme (MÖ 400- MS 1937), Türk Yurdu, (310), 198-213.

Üstün Demirkaya, F. (2014). Toplumsal dinamikler bağlamında Trabzon kent dokusunun dönüşümü (Komnenos Hanedanlığı'ndan Cumhuriyet'e kadar) (Yayımlanmamış doktora tezi). Karadeniz Teknik Üniversitesi, Trabzon.

Üstün Demirkaya, F. ve Tuluk, Ö. (2018). Komnenos Hanedanlığı'ndan Osmanlı'ya Trabzon Mahalleleri: Kentsel Dinamikler Bağlamında Bir Fiziksel Gelişim Okuması. A. S. Kubat ve diğerleri (Ed.), Türkiye Kentsel Morfoloji Araştırma Ağı II. Kentsel Morfoloji Sempozyumu Bildiri Kitabı (s. 713-724). İstanbul: MBB Kültür Yayınları.

Yılmaz, Ö. (2006). Batılı seyyahlara göre Trabzon (1808-1878) (Yayımlanmamış yüksek lisans tezi). Karadeniz Teknik Üniversitesi, Trabzon.

Yılmaz, Ö. (2015). Dussaud biraderlerin Trabzon limanı inşa projesi (1870). Karadeniz İncelemeleri Dergisi, (18), 213-244. 